\title{
Does Majority Voting Improve Board Accountability?
}

\author{
Stephen J. Choi† \\ Jill E. Fisch †† \\ Marcel Kahan $\ddagger$ \\ Edward B. Rock $\neq$
}

Directors have traditionally been elected by a plurality of the votes cast. This means that in uncontested elections, a candidate who receives even a single vote is elected. Proponents of shareholder democracy have advocated a shift to a majority voting rule, in which a candidate must receive a majority of the votes cast to be elected. Over the past decade, they have been successful, and the shift to majority voting has been one of the most popular and successful governance reforms.

Yet critics are skeptical as to whether majority voting improves board accountability. Tellingly, directors of companies with majority voting rarely fail to receive majority approval - even more rarely than directors of companies with plurality voting. Even when such directors fail to receive majority approval, they are unlikely to be forced to leave the board. This poses a puzzle: Why do firms switch to majority voting, and what effect, if any, does the switch have on director behavior?

We empirically examine the adoption and impact of a majority voting rule using a sample of uncontested director elections from 2007 to 2013. We test and find partial support for four hypotheses that could explain why directors of majority voting firms so rarely fail to receive majority support: selection, deterrence or accountability, electioneering by firms, and restraint by shareholders.

Our results further suggest that the reasons for and effects of adopting majority voting may differ between early and late adopters. We find that early adopters of majority voting were more shareholder responsive than other firms, even before they adopted majority voting. These firms seem to have adopted majority voting voluntarily, and the adoption of majority voting has made little difference in their responsiveness to shareholders going forward. By contrast, for late adopters we find no evidence that they were more shareholder responsive than other firms before they

$\dagger$ Murray and Kathleen Bring Professor of Law, New York University School of Law.

†† Perry Golkin Professor of Law, University of Pennsylvania Law School.

$\$$ George T. Lowy Professor of Law, New York University School of Law.

\# Professor of Law, New York University School of Law. Thanks to Bill Allen, Michal Barzuza, Ryan Bubb, Emiliano Catan, John Coates, Ed Durkin, Wei Jiang, Tom Lin, Susan Permut, Roberta Romano, Simone Sepe, and Jennifer Shotwell for comments on earlier drafts. We are also grateful for comments we received at the University of Pennsylvania Institute for Law and Economics Corporate Roundtable, the Harvard Law School Law and Economics Seminar, the Law and Economics Colloquium at the University of Virginia Law School, the NYU/Penn Conference on Law and Finance, the Hebrew University of Jerusalem Law and Finance Workshop, and the Annual Meeting of the American Law and Economics Association. 
adopted majority voting, but we find strong evidence that they became more responsive after adopting majority voting.

Differences between early and late adopters can have important implications for understanding the spread of corporate governance reforms and evaluating their effects on firms. Rather than targeting the firms that, by their measures, are most in need of reform, reform advocates instead seem to have targeted the firms that were already the most responsive. These advocates may then have used the widespread adoption of majority voting to create pressure on the nonadopting firms to conform. Empirical studies of the effects of governance changes thus need to be sensitive to the possibility that early adopters and late adopters of reforms differ from each other and that the reforms may have different effects on these two groups of firms.

INTRODUCTION ........................................................................................ 1120

I. The Shift From Plurality to Majority Voting................................... 1124

II. Possible Explanations for the Different Voting Patterns ............. 1129

III. EMPIRICAL ANALYSIS .................................................................... 1135

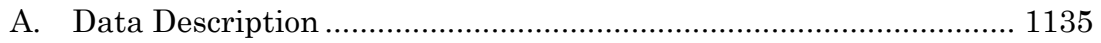

B. Data Analysis ...................................................................... 1139

1. The selection hypothesis: Are companies that adopted majority voting different from those that did not?. 1139

2. The causation hypothesis: the effects of majority voting on subsequent electoral success............................................. 1148

3. The deterrence or accountability hypothesis: the effect of the MVR on primary conduct.

4. The electioneering and shareholder-restraint hypotheses: majority withhold votes given primary conduct................... 1166

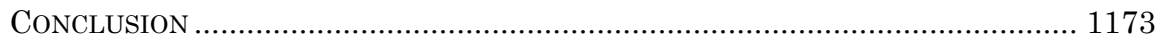

APPENDIX. VARIABLE DEFINITIONS........................................................... 1176

\section{INTRODUCTION}

Directors have long been elected by a plurality of the votes cast. ${ }^{1}$ In uncontested elections, this means that a candidate who

1 See, for example, 8 Del Code Ann $\S 216$ ("In the absence of such specification in the certificate of incorporation or bylaws of the corporation ... [d]irectors shall be elected by a plurality of the votes of the shares present in person or represented by proxy at the meeting and entitled to vote on the election of directors.”); Model Bus Corp Act § 7.28(a) (2011) ("Unless otherwise provided in the articles of incorporation, directors are elected by a plurality of the votes cast by the shares entitled to vote in the election at a meeting at which a quorum is present."). Prior to 1987, Delaware law required the affirmative vote of a majority of the shares present for the election of directors. See 8 Del Code Ann $\S 216$ (1983). 
receives even a single vote is elected.$^{2}$ Because most director elections are uncontested, ${ }^{3}$ proponents of shareholder democracy have long decried the traditional plurality voting rule (PVR). ${ }^{4}$ Instead, they favor a majority voting rule (MVR) according to which a candidate must receive a majority of the votes cast to be elected. ${ }^{5}$

Over the last decade, the move from plurality to majority voting for corporate directors has been one of the most popular and successful corporate governance reform efforts. ${ }^{6}$ As recently as 2005 , only nine of the S\&P 100 companies used majority voting in director elections. ${ }^{7}$ The shift since then has been dramatic. As of January 2014, almost 90 percent of S\&P 500 companies have adopted some form of majority voting. ${ }^{8}$

Advocates of majority voting argue that it is a critical tool for maintaining director accountability to shareholders. In the words of the Council for Institutional Investors, "[m]ajority voting ensures that shareowners' votes count and makes directors more accountable to the shareowners they represent."9 Accepting this premise, the Toronto Stock Exchange recently amended its company manual to require majority voting for listed companies. ${ }^{10}$

2 State law governs the power of shareholders to nominate director candidates. Jill E. Fisch, From Legitimacy to Logic: Reconstructing Proxy Regulation, 46 Vand L Rev 1129, 1144 (1993). Our analysis focuses exclusively on uncontested elections.

3 See Lee Harris, Missing in Activism: Retail Investor Absence in Corporate Elections, 2010 Colum Bus L Rev 104, 120-21 (reporting that, over the time period from 1999 to 2008 , the average number of contested elections at public companies was about thirtysix per year).

4 See, for example, Jeff Mahoney, General Counsel of the Council of Institutional Investors, Letter to John Carey, Vice President of Legal for NYSE Regulation, Inc *4 (June 20, 2013), archived at http://perma.cc/X4PT-PKJW (terming the plurality voting process as "antiquated, or as some have described 'truly bizarre").

5 Yonca Ertimur, Fabrizio Ferri, and David Oesch, Does the Director Election System Matter? Evidence from Majority Voting, 20 Rev Accounting Stud 1, 2 (2015).

$6 \quad$ See Bo Becker and Guhan Subramanian, Improving Director Elections, 3 Harv Bus L Rev 1, 10 (2013) (describing a "rapid proliferation of majority vote requirements among U.S. companies").

7 Marcel Kahan and Edward Rock, Embattled CEOs, 88 Tex L Rev 987, 1011 (2010).

8 Marc S. Gerber, US Corporate Governance: Boards of Directors Face Increased Scrutiny, in Thomas H. Kennedy, et al, eds, 2014 Insights *157, 157 (Skadden, Arps, Slate, Meagher \& Flom LLP), archived at http://perma.cc/SKC3-HXCE.

9 Majority Voting for Directors (Council of Institutional Investors, 2013), archived at http://perma.cc/5MNV-P9JE.

10 Toronto Stock Exchange Mandates Majority Voting to Further Enhance Corporate Governance (TMX Group, Feb 13, 2014), archived at http://perma.cc/8XPC-PTUX (announcing the adoption of a "majority voting" requirement that may be satisfied by a policy requiring a director to tender a resignation if the director receives more "withhold" than "for" votes). The Council for Institutional Investors has petitioned the NYSE and NASDAQ to do the same. See Majority Voting for Directors (cited in note 9). 
Yet critics of majority voting are skeptical. One recent article argues that majority voting "is little more than smoke and mirrors." 11 Another characterizes majority voting as a "paper tiger."12 A striking finding from our data is that under plurality voting, the likelihood that a director fails to receive a majority "for" vote is nineteen times higher than under majority voting ( 0.622 percent versus 0.033 percent). ${ }^{13}$ Of over twenty-four thousand director nominees at S\&P 1500 companies who were subject to an MVR in elections between 2007 and 2013, only eight failed to receive a majority of "for" votes. ${ }^{14}$ Even when a director fails to receive a majority, that director might not actually leave the board. Rather, such a director stays on until the director resigns, the director is removed, or a successor is elected. ${ }^{15}$ In fact, in our sample, of the eight directors at MVR firms who failed to receive a majority, only three actually left the board following the election. ${ }^{16}$

These findings raise two related issues. First, what accounts for the different voting patterns under PVRs and MVRs? Second, given that the direct effect of majority voting is negligible-a shareholder power to remove directors that is exercised at the

11 William K. Sjostrom Jr and Young Sang Kim, Majority Voting for the Election of Directors, 40 Conn L Rev 459, 487, 489 (2007) (conducting an event study and finding "no statistically significant market reaction" to a company's adoption of majority voting).

12 Jay Cai, Jacqueline L. Garner, and Ralph A. Walkling, A Paper Tiger? An Empirical Analysis of Majority Voting, 21 J Corp Fin 119, 120 (2013) (finding that the "adoption of majority voting has little effect on director votes, director turnover, or improvement of firm performance").

13 See Part II.

14 See Part III.A.

15 Majority voting provisions typically require a director who fails to receive a majority to tender his or her resignation, but the board need not accept that resignation. It is not unusual for a board to refuse to accept the director's proffered resignation. See Jeff Green, America's Teflon Corporate Boards (Bloomberg, July 14, 2011), archived at http://perma.cc/GJC3-ZGQ8. The limited effectiveness of the shareholder vote was powerfully illustrated at the May 2011 annual meeting of IRIS International (an issuer not in our sample), at which none of the nine director candidates received a majority of votes in favor. The directors then submitted their resignations, and the board voted not to accept them. Bloomberg has described boards that fail to remove an outvoted director as "Teflon Corporate Boards.” Id.

16 A separate study of Russell 3000 majority voting firms also found that directors who failed to receive a majority vote were only sometimes removed. For a more detailed examination of five of these cases, see Becker and Subramanian, 3 Harv Bus L Rev at 1314 (cited in note 6) (reporting that boards accepted resignations of only two of five such directors and one such acceptance was because of a state mandate). See also Kimberly Gladman, Agnes Grunfeld, and Michelle Lamb, The Election of Corporate Directors: What Happens When Shareowners Withhold a Majority of Votes from Director Nominees? *2 (IRRC Institute, Aug 2012), archived at http://perma.cc/R6AW-B8ZL (reporting that "[o]nly $5 \%$ of the majority withhold votes in our study [of 175 director nominees from Russell 3000 firms] led directly to director removal"). 
rate of one in eight thousand is hardly worth mentioning-does majority voting have more significant indirect effects on board accountability? That is, does the possibility that a nominee may fail to get a majority of "for" votes, and thereby face an increased risk of losing his or her board seat, encourage directors to be more responsive to shareholder interests?

At first blush, it may appear that majority voting could generate substantial indirect effects and that the reason directors fare better under majority voting is because they are more responsive to shareholders. As we detail below, ${ }^{17}$ directors who are subject to majority voting are more likely to attend board meetings regularly and less likely to receive a "withhold" recommendation from Institutional Shareholder Services, Inc ${ }^{18}$ (ISS) than directors who are subject to plurality voting.

There are, however, alternative explanations for these differences. For example, causality may run in the other direction: Companies that are more responsive to shareholders may be more likely to adopt majority voting, and majority voting may have no effect on director actions. Or companies subject to majority voting may lobby ISS more heavily to avert a "withhold" recommendation.

In this Article, we empirically examine the different impacts of an MVR using a sample of uncontested director elections from 2007 to 2013. The Article proceeds as follows: In Part I, we offer a brief background on the shift to a majority voting standard among large publicly traded issuers. In Part II, we describe in more detail four hypotheses that could explain the discrepancy between the likelihood that a director candidate will fail to get a majority of "for" votes under the different voting rules. We then proceed to test the hypotheses. In Part III, we describe the data set, the tests we performed, and the results.

While we find some support for all four hypotheses, our most dramatic results indicate differences between early and late adopters with respect to the adoption and effect of majority voting. Specifically, we find strong evidence of selection effects for early adopters; firms that adopted majority voting early had more success in director elections and more shareholder-oriented corporate governance prior to the adoption. In contrast, we find the adoption

17 See Parts III.B.3-4.

18 Institutional Shareholder Services is the dominant proxy advisory firm. See Stephen J. Choi, Jill E. Fisch, and Marcel Kahan, Director Elections and the Role of Proxy Advisors, 82 S Cal L Rev 649, 651-52 (2009) (describing the role and influence of ISS and other proxy advisors). 
of majority voting by late adopters led to more shareholder-friendly governance. These findings suggest that investors, perhaps counterintuitively, may have employed a strategy of targeting shareholder-responsive firms first, rather than focusing on those companies most in need of governance reform.

As far as we know, this is the first time that this difference has been established empirically. As we discuss in more detail below, this difference, especially if generalizable to the adoption of other corporate governance reforms, has broad implications. In particular, empirical studies of the adoption and effect of governance reform should be sensitive to potential differences between early and late adopters. These differences also suggest that early evaluations of a particular reform may understate the effect of the reform to the extent that the reform has not yet spread to those firms most likely to be affected by its adoption. Our study highlights the importance of considering these differences in future research analyzing other reforms, such as proxy access, bylaws enabling shareholders to request special meetings, and the separation of positions of chair and CEO.

\section{The SHIFT FROM PluRALITY TO MAJORITY Voting}

Traditionally, directors in most companies were elected by a plurality of the votes cast. ${ }^{19}$ This plurality standard was (and remains) the default rule in Delaware and most other states. ${ }^{20} \mathrm{~A}$ problem with the traditional plurality standard is that it has little meaning in an uncontested election, which most board elections are. ${ }^{21}$ If the number of nominees to the board is equal to the number of board seats to be filled, every nominee who receives at least one vote will be elected. As a result, even a nominee who has minimal support among shareholders is assured of getting on the

\footnotetext{
19 See note 1.

20 See 8 Del Code Ann $\S 216$. Very few states provide for a non-PVR default. See Ala Code Ann § 10A-2-7.28; Alaska Stat Ann § 10.06.415; 805 ILCS 5/7.60; Mo Ann Stat $\S 351.265$ (providing that an MVR is the default for corporations that do not have cumulative voting); ND Cent Code § 10-35-09 (same); NM Stat Ann § 53-11-32; SD Cod Laws $\S \S 47-1 \mathrm{~A}-725,-728$. See also Mary Siegel, The Holes in Majority Voting, 2011 Colum Bus L Rev 364, 369 \& n 18 ("Only five states, however, provide majority voting as the default rule.").

21 See Harris, Missing in Activism, 2010 Colum Bus L Rev at 120-21 (cited in note 3).
} 
board. ${ }^{22}$ Similarly, in the absence of a competing nominee, disgruntled shareholders cannot unseat a director by failing to vote in favor of his or her election. ${ }^{23}$

Shareholder inability to cast an effective vote against director candidates has not prevented shareholders from expressing their dissatisfaction with director nominees. In 1993, Professor Joseph Grundfest published an article urging investors to engage in symbolic "vote no" campaigns to express concerns about an issuer's performance. ${ }^{24}$ Institutional investors began to engage in "withhold"-vote campaigns. ${ }^{25}$ One highly publicized example was the effort led by the California Public Employees' Retirement System (CalPERS) to "withhold" votes at Disney from director nominee Michael Eisner. ${ }^{26}$ The effort was enhanced by the growing influence of proxy advisory firms such as ISS, ${ }^{27}$ which offer institutional investors recommendations on which director nominees to target with "withhold" votes. ${ }^{28}$

Beginning in 2005, shareholder activists began to push for changes in the voting standard. ${ }^{29}$ Initially, some issuers adopted

22 As officers and directors virtually always hold at least some stock, the election of the issuer's nominees in an uncontested election with a PVR is a virtual certainty. See, for example, Trends in Board of Director Compensation (Harvard Law School Forum on Corporate Governance and Financial Regulation, Apr 13, 2015), archived at http://perma.cc/M5VZ-BLRL (noting that "companies typically provide [] equity awards and require minimum stock ownership" of directors).

23 See Joann S. Lublin, Directors Lose Elections, but Not Seats (Wall St J, Sept 28, 2009), online at http://www.wsj.com/articles/SB125409320578444429 (visited July 9, 2016) (Perma archive unavailable) (reporting that ninety-three board members at fifty issuers received less than a majority of votes cast during 2009 , but that none lost a board seat because they all served at issuers with plurality voting).

24 See generally Joseph A. Grundfest, Just Vote No: A Minimalist Strategy for Dealing with Barbarians inside the Gates, 45 Stan L Rev 857 (1993).

25 See Diane Del Guercio, Laura Seery, and Tracie Woidtke, Do Boards Pay Attention When Institutional Investor Activists “Just Vote No"?, 90 J Fin Econ 84, 85 (2008) (studying 112 publicly announced "just vote no" campaigns sponsored by institutional investors between 1990 and 2003).

26 See Bruce Orwall, Calpers to Withhold Voting for Eisner (Wall St J, Feb 26, 2004), online at http://www.wsj.com/articles/SB107774511301139206 (visited Dec 5, 2015) (Perma archive unavailable).

27 See Stephen Choi, Jill Fisch, and Marcel Kahan, The Power of Proxy Advisors: Myth or Reality?, 59 Emory L J 869, 870-71 (2010) (describing the services provided by proxy advisors).

28 See Stephen Choi, Jill Fisch, and Marcel Kahan, Who Calls the Shots? How Mutual Funds Vote on Director Elections, 3 Harv Bus L Rev 35, 39 (2013). For further analysis on the role and influence of proxy advisors, see generally Yonca Ertimur, Fabrizio Ferri, and David Oesch, Shareholder Votes and Proxy Advisors: Evidence from Say on Pay, $51 \mathrm{~J}$ Accounting Rsrch 951 (2013).

29 The Carpenter Pension Funds appear to have introduced the first shareholder proposals seeking an MVR. The Funds submitted twelve such proposals during the 2004 
a director-resignation policy - a board policy requiring each board nominee to submit a conditional offer to resign if he or she does not receive a majority of the votes cast at the next election. ${ }^{30}$ Later on, issuers amended their bylaws or charters to adopt a majority standard for uncontested director elections. Under the strict majority standard, a nominee is elected only if he or she receives more "for" votes than "against" votes. ${ }^{31}$

Even under a strict majority standard, in which a nominee is not elected if he or she does not get a majority of "for" votes, a failure to be elected does not automatically mean that the nominee will be removed from the board. ${ }^{32}$ Under the laws of Delaware and many other states, an incumbent director continues as a holdover director until the director resigns, the director is removed, or a successor is elected. ${ }^{33}$ Thus, even if an incumbent director fails to secure a majority of "for" votes, the director often stays in office, at least for the time being. In addition, statutes generally provide, at least as a default matter, that the board of directors has the authority to fill vacancies on the board. ${ }^{34}$ As a legal matter, nothing prevents the board from appointing the very person who failed to receive a majority of "for" votes to fill the vacancy.

proxy season. See Douglas J. McCarron, President of the United Brotherhood of Carpenters and Joiners of America, Letter to Brent J. Fields, Secretary of the SEC *3 n 11 (Mar 10, 2015), archived at http://perma.cc/KJB9-FSFY (describing the history of the Carpenter Funds' use of MVR proposals). The MVR movement gained visibility when reporter Louis Lavelle published a January 2005 article in BusinessWeek. See Louis Lavelle, A Simple Way to Make Boards Behave, BusinessWeek 38 (Jan 31, 2005).

30 See Cai, Garner, and Walkling, 21 J Corp Fin at 120-21 (cited in note 12) (describing and distinguishing director-resignation policies from "true majority" mechanisms).

31 Notably, even the strictest standard requires only that a director candidate receive a majority of votes cast. In contrast, some corporate issues, such as approval of a merger, require an affirmative vote by a majority of outstanding shares. See, for example, 8 Del Code Ann $\S 251$ (c).

Note also that there is a distinction between "against" and "withhold" votes. Under an MVR, shareholders who oppose election can vote "against"; under a PVR, shareholders who oppose election can only "withhold" their vote. See generally Securities and Exchange Commission, Release No 34-16356: Shareholder Communications, Shareholder Participation in the Corporate Electoral Process and Corporate Governance Generally, 44 Fed Reg 68764, 68765 (1979), amending various sections of CFR Title 17. Because this Article compares MVR and PVR companies, we often use the terms interchangeably.

32 Siegel, 2011 Colum Bus L Rev 364, 374-80 (cited in note 20).

33 See, for example, 8 Del Code Ann § 141(b). See also Siegel, 2011 Colum Bus L Rev at 375-78 (cited in note 20) (discussing various states' "holdover rule" statutory schemes). But see Model Bus Corp Act $\S \S 8.05,10.22$ (2011) (providing an abbreviated holdover period of ninety days for directors who are not reelected in a company that has adopted majority voting).

34 See, for example, 8 Del Code Ann § 223. 
MVRs have been embraced by both investors and issuers. ${ }^{35}$ As a result, the movement from plurality to majority voting has been relatively rapid, especially at large companies. Some type of MVR was used by approximately 16 percent of S\&P 500 companies in February 2006. ${ }^{36}$ As of January 2014, approximately 90 percent of S\&P 500 companies used some form of majority voting. ${ }^{37}$ The shift to majority voting at smaller companies has been less pronounced. As of 2012, 52 percent of mid-cap companies had adopted majority voting. ${ }^{38}$ The percentage of small-cap companies with majority voting as of 2012 was far lower-only 19 percent. ${ }^{39}$

Many commentators have argued that majority voting enhances director accountability to shareholders. In 2005, then-ISS Vice President Stephen Deane wrote that majority voting "holds the potential to enable a new era in constructive dialogue between corporations and their owners." 40 The Council of Institutional Investors supported the adoption of majority voting and urged the NYSE and NASDAQ to impose a majority voting requirement as a listing standard. ${ }^{41}$ Professor Lucian Bebchuk wrote that "given the clear and widely accepted flaws of plurality voting, majority voting should be the default arrangement." 42 Professor Lisa Fairfax argued that "[t]o the extent the threat of losing a board seat impacts board behavior, majority voting increases shareholders' ability to influence board behavior." 43

35 See, for example, Stephen Deane, Majority Voting in Director Elections: From the Symbolic to the Democratic *6 (ISS, 2005), archived at http://perma.cc/ZT4W-3DCV (describing initiatives by both investors and issuers seeking to implement majority voting); Committee on Corporate Laws of the Section of Business Law of the American Bar Association, Preliminary Report of the Committee on Corporate Laws on Voting by Shareholders for the Election of Directors *21-26 (Jan 17, 2006), archived at http://perma.cc/FHC7-CC3T (proposing an enabling approach to majority voting).

36 Claudia H. Allen, Study of Majority Voting in Director Elections *i (Neal, Gerber \& Eisenberg LLP, Nov 12, 2007), archived at http://perma.cc/X4JH-LZM7.

37 Gerber, Boards of Directors Face Increased Scrutiny at *157 (cited in note 8).

38 Governance Trends and Practices at US Companies: A Review of Small-and Midsized Companies * 10 (Ernst \& Young, May 2013), archived at http://perma.cc/5ZYF-9EDZ ("From 2007 to 2012, the proportion of small-cap companies with majority voting provisions in director elections has grown from $7 \%$ to $19 \%$ and the proportion of mid-cap companies has jumped dramatically from $18 \%$ to $52 \%$.").

39 Id.

40 Deane, Majority Voting in Director Elections at *1 (cited in note 35).

41 Marcel Kahan and Edward Rock, Symbolic Corporate Governance Politics, 94 BU L Rev 1997, 2010 (2014).

42 Lucian A. Bebchuk, The Myth of the Shareholder Franchise, 93 Va L Rev 675, 702 (2007).

43 Lisa M. Fairfax, Mandating Board-Shareholder Engagement?, 2013 U Ill L Rev 821,826 (2013). 
Few studies have examined the effect of majority voting empirically. An early study by Professors William Sjostrom and Young Sang Kim looked at stock price reactions to firms' adoptions of majority voting and found no statistically significant market reactions. ${ }^{44}$ The study suggested that the lack of impact was due, in part, to the fact that majority voting does not in fact "give[] shareholders veto power over incumbent directors." 45 Rather, the authors concluded, MVRs were "smoke and mirrors" because the board ultimately had the power to retain a losing director. ${ }^{46}$

Professors Jie Cai, Jacqueline Garner, and Ralph Walkling looked at 481 firms that adopted majority voting from 2004 to 2007.47 Their study found that early adopters initially experienced positive abnormal returns in response to the adoption announcement. ${ }^{48}$ The study found that, over a one-year time period, however, the "adoption of majority voting has little effect on director votes, director turnover, or improvement of firm performance." 49 Importantly, although poorly performing firms were more likely to adopt an MVR, their performance continued to deteriorate after the adoption of majority voting. ${ }^{50}$ The authors therefore concluded that majority voting was a "paper tiger." ${ }_{51}$

Finally, Professors Yonca Ertimur, Fabrizio Ferri, and David Oesch looked at shareholder proposals on majority voting. ${ }^{52}$ Using a regression-discontinuity design, they showed that the adoption of these proposals is associated with a positive abnormal stock price return.53 Moreover, using a matched sample (based on propensity scores), they found that firms that have adopted majority voting are more likely to implement shareholder proposals ${ }^{54}$ and less likely to experience high levels of "withhold" votes for directors in consecutive annual meetings. ${ }^{55}$

44 See Sjostrom and Kim, 40 Conn L Rev at 489-90 (cited in note 11). The study looked at 116 firms that adopted or announced that they would adopt majority voting between September 2004 and October 2006. Id.

45 Id at 486 .

46 Id at 487.

47 Cai, Garner, and Walkling, 21 J Corp Fin at 123 (cited in note 12).

48 Id at $129-30$.

49 Id at 120

50 Id at $131-32$.

51 Cai, Garner, and Walkling, $21 \mathrm{~J}$ Corp Fin at 133 (cited in note 12).

52 See generally Ertimur, Ferri, and Oesch, 20 Rev Accounting Stud 1 (cited in note 5).

53 Id at $6-16$.

54 Id at $17-27$.

55 Id at $27-32$. 
This Article contributes to this literature by distinguishing among, and empirically examining, several possible explanations for the differential voting patterns observed between firms that employ plurality voting and those that employ majority voting. Moreover, this Article is the first to differentiate early adopters of majority voting from late adopters and to present evidence that factors explaining the voting patterns differ significantly for these two sets of firms.

\section{Possible Explanations For the DifFEREnT Voting PATTERNS}

Elections governed by an MVR exhibit a strikingly different vote pattern from elections governed by a PVR. As noted above, directors elected under an MVR are far more likely to receive a majority "for" vote. In our sample, which consists of almost sixtyfive thousand uncontested director elections at S\&P 1500 companies between 2007 and 2013, only 0.033 percent of director nominees in elections governed by an MVR failed to receive a majority of votes cast. By contrast, in elections governed by a PVR, 0.622 percent of candidates failed to garner a majority. The difference is statistically significant at the 1 percent level.

Table 1 reports summary statistics on the fraction of directors that failed to receive a majority "for" vote. We also report the summary statistics for subsets of our sample divided according to market capitalization.

Several hypotheses may account for the difference in voting patterns between MVR and PVR firms. Companies that adopt majority voting may simply be different from companies that do not. This is a standard selection effect-"good" companies selfselect into adopting majority voting. ${ }^{56}$ Ex post, nominees at these companies are less likely to receive a high "withhold" vote, but this effect is not caused by majority voting but rather by the underlying good-governance factors that led the company to adopt majority voting. We refer to this explanation as the selection hypothesis.

Alternatively, the different voting patterns may be caused by the difference in voting rules. We refer to this explanation as the causation hypothesis. In particular, there are three different ways

56 We put "good" in quotation marks because good merely connotes a lower ex ante likelihood of having a nominee receive a high "withhold" vote. This does not suggest that it is always or even generally best for companies and directors to avoid taking actions that cause high "withhold" votes. We could equally well describe this as "shareholder responsive" or, as we will see, "ISS compliant." 
in which the voting rules may cause differential voting patterns, each with different normative implications. The first possibility, that an MVR increases director accountability by making directors more responsive to shareholder interests, is what has driven investors to support the implementation of majority voting. ${ }^{57} \mathrm{We}$ refer to this form of the causation hypothesis as the deterrence (or accountability) hypothesis. Notably, confirming the deterrence hypothesis does not necessarily demonstrate that directors who are subject to majority voting are making better decisions. Catering to shareholders may not lead to increased firm value. ${ }^{58}$ Indeed, skeptics might describe the deterrence effect as making directors more responsive to ISS, given the reputed influence of ISS over shareholder voting decisions. ${ }^{59}$ To avoid the implication that an MVR induces superior decisions, we use the term "shareholder friendly" or "shareholder responsive" governance to refer to actions that have a lower likelihood of inducing "withhold" votes.

A second possibility is that companies that have adopted majority voting may engage in more campaigning in close elections because the implications of receiving a majority "withhold" vote are more severe. Relatedly, these companies may lobby ISS harder not to issue a "withhold" recommendation. We refer to this form of the causation hypothesis as the electioneering hypothesis.

ISS has a practice of notifying S\&P 500 companies that it intends to issue a "withhold" recommendation and offering them a forty-eight-hour window during which they can engage with ISS about the recommendation. ${ }^{60} \mathrm{It}$ is commonplace for issuers to engage with ISS, both during this window and otherwise, in an attempt to influence ISS's recommendations. ${ }^{61}$ Upon receiving such a warning, MVR companies may make greater efforts to persuade

57 See, for example, Mahoney, Letter to John Carey at *4 (cited in note 4), quoting U.S. Financial Regulatory Reform: The Investors' Perspective *22 (Investors' Working Group, July 2009), archived at http://perma.cc/QU9D-NDFV (explaining that "[p]lurality voting in uncontested situations results in 'rubber stamp' elections").

58 Compare generally William W. Bratton and Michael L. Wachter, The Case against Shareholder Empowerment, 158 U Pa L Rev 653 (2010), with Lucian Arye Bebchuk, The Case for Increasing Shareholder Power, 118 Harv L Rev 833 (2005).

59 See Choi, Fisch, and Kahan, 59 Emory L J at 871-72 (cited in note 27) (recounting various estimates of ISS's influence on shareholder voting).

60 Holly J. Gregory, How to Address ISS \& Glass Lewis Policy Changes (Harvard Law School Forum on Corporate Governance and Financial Regulation, Jan 17, 2013), archived at http://perma.cc/MC9B-N9ZA.

61 See Ning Chiu, Conversation with ISS about Issuer Engagement with ISS (Davis Polk \& Wardwell LLP, Mar 10, 2014), archived at http://perma.cc/7SVC-ZS7R (reporting on an interview with Marc Goldstein, head of issuer engagement at ISS). 


\section{TABLE 1. Summary Statistics: Fraction of DiREctors Who FAILED TO RECEIVE A MAJORITY “FOR” VOTE}

\begin{tabular}{lllll} 
& Plurality & Majority & Difference & $\begin{array}{l}\text { Standard } \\
\text { Error }\end{array}$ \\
\hline \hline Full Sample & 0.00622 & 0.00033 & $0.0059^{* *}$ & 0.0014 \\
$\begin{array}{l}\text { Firms with Market } \\
\text { Capitalization } \\
\leq \$ 1 \text { Billion }\end{array}$ & 0.01143 & 0.00000 & $0.0114^{+}$ & 0.0065 \\
$\begin{array}{l}\text { Firms with Market } \\
\text { Capitalization }\end{array}$ & 0.00460 & 0.00026 & $0.0043^{*}$ & 0.0017 \\
$>\$ 1$ Billion and $\leq \$ 10$ & & & & \\
$\begin{array}{l}\text { Billion } \\
\text { Firms with Market }\end{array}$ & 0.00350 & 0.00041 & $0.0031^{*}$ & 0.0016 \\
Capitalization & & & & \\
$>\$ 10$ Billion & & & & \\
\hline
\end{tabular}

Note: The $\$ 1$ billion cutoff corresponds approximately to the twenty-fifth percentile for market capitalization of the sample firms. The $\$ 10$ billion cutoff corresponds approximately to the seventy-fifth percentile for market capitalization of the sample firms. The Difference column reports the difference between the Plurality and Majority columns. The Standard Error column reports the standard error of the difference, clustered at the company level. For an example of a comparison of director characteristics using the standard error clustered at the company level, see Vyacheslav Fos and Margarita Tsoutsoura, Shareholder Democracy in Play: Career Consequences of Proxy Contests, $114 \mathrm{~J}$ Fin Econ 316, 322 (2014). The Difference column also reports the statistical significance of the difference as follows: ${ }^{+} p<0.10,{ }^{*} p<0.05,{ }^{* *} p<0.01$.

ISS not to issue that recommendation than PVR companies do. Because a positive ISS recommendation virtually guarantees that the election will not be close, ${ }^{62}$ persuading ISS not to issue a negative recommendation is an effective strategy to guarantee a majority "for" vote.

In addition to lobbying ISS, companies can address shareholders directly. Companies can communicate individually with larger institutional investors to explain why a nominee should be elected and the value of the nominee to the company. They might also hint that the company would not look favorably on any institution that votes against the nominee or that the company would be less inclined to answer questions by investment professionals 
who work for such an institution. Companies can also communicate publicly with shareholders through formal proxy solicitation materials. Companies can engage the services of a proxy solicitation firm to communicate with shareholders, and can increase the efforts exerted by such a firm in the case of a close election. All these solicitation efforts entail costs, but when the consequences of failing to get a majority of "for" votes are more severe, as they are under an MVR, companies may be more willing to incur these costs.

Notably, companies know when an election is likely to be close. Indeed, they have detailed information about the preliminary voting tallies well before the shareholders meeting. Historically, Broadridge Financial Solutions, the firm that runs the mechanics of proxy solicitation and vote tabulation, ${ }^{63}$ has provided interim voting information to issuers from the date that the proxy materials are distributed to investors up through the date of the shareholders meeting. ${ }^{64}$ This information enables companies to predict the outcome of the vote and to shape their shareholderengagement policies accordingly. ${ }^{65}$

Finally, shareholders may be more reluctant to cast a vote against a nominee when a failure to get a majority of "for" votes could result in the ouster of the nominee. Shareholders may view casting a "withhold" vote under a PVR as a symbolic protest vote. Indeed, when Professor Grundfest first popularized "vote no" campaigns as a way to deal with legal developments that reduced the effectiveness of the market for corporate control as a form of discipline, he explicitly extolled the value of such campaigns as a symbolic gesture rather than a tool with a meaningful potential

63 See Eleanor Bloxham, The Secret Power Player behind Almost All Shareholder Votes (Fortune, Feb 13, 2014), archived at http://perma.cc/Z2PB-MCSJ (describing the work of Broadridge).

64 See Recommendations of the Investor Advisory Committee: Impartiality in the Disclosure of Preliminary Voting Results *2-3 (Oct 9, 2014), archived at http://perma.cc/ZHA3-HNSB (describing Broadridge's "real-time" provision of "preliminary proxy results" to issuers in the days leading up to the meeting); Proxy Vote Reporting and "Interim Vote Status Information" *2 (Broadridge, Apr 2014), archived at http://perma.cc/KNR4-LHNE (explaining Broadridge's policies for providing interim voting information).

65 See Karlee Weinmann, Broadridge Calls Off Controversial Proxy Vote Reforms (Law360, Feb 10, 2014), archived at http://perma.cc/2W86-HDES (explaining that the provision of interim voting information enables participants in an election "to predict the likely outcome, understand voter trends and shape their shareholder outreach efforts around them"). 
for changing board composition. ${ }^{66}$ In contrast, shareholders may be concerned that a failure to elect a full slate of directors at a company with an MVR may interfere with board functioning and therefore may be reluctant to cast "no" votes. Similarly, Professors Cai, Garner, and Walkling suggest that institutional investors may fear that such a failure would adversely affect stock price and, as a result, may be more reluctant to vote against a director in a majority voting firm. ${ }^{67}$ We refer to this form of the causation hypothesis as the shareholder-restraint hypothesis.

In an earlier article, two of us analyzed the consequences of majority "withhold" votes at companies using a PVR. ${ }^{68}$ In examining Russell 3000 companies in the 2008 and 2009 proxy seasons, we found that only 3 of 112 director nominees who failed to receive a majority vote under a PVR left the board, at least immediately-a much lower percentage than our results here for nominees at companies using an MVR. ${ }^{69}$ However, for about twothirds of the other nominees, the company and the director took steps that effectively addressed the underlying reason for the high "withhold" vote. ${ }^{70}$ We concluded that "withhold" votes at companies with plurality voting were effective in inducing companies and directors to change their behavior (though not in inducing a change in board composition).

Moreover, because most shareholders seem satisfied if companies and directors change their behavior-as judged by the low percentage of "withhold" votes received in subsequent elections by nominees who took corrective measures but remained on the board-we conjectured that the main aim of "withhold" votes at

66 See Grundfest, 45 Stan L Rev at 865 (cited in note 24) (“The effect of a 'just vote no' campaign is thus purely symbolic: It will not oust incumbent directors or executives, nor will it upset the corporation's formal governance structure.").

67 See Cai, Garner, and Walkling, 21 J Corp Fin at 122 (cited in note 12). In an earlier article, these authors found that firms with majority voting receive higher director-approval rates than firms with plurality voting. See Jie Cai, Jacqueline L. Garner, and Ralph A. Walkling, Electing Directors, 64 J Fin 2389, 2401 (2009).

68 See Marcel Kahan and Edward Rock, The Insignificance of Proxy Access, $97 \mathrm{Va} \mathrm{L}$ Rev 1347, 1420-25 (2011).

69 Id at 1420. The sample included 1 director who lost an election under an MVR, making the total number of director nominees who left the board immediately after failing to receive a majority vote 4 out of 113 . Id.

70 Id at 1421. This estimate is based on the responses of companies with "nominees who did not leave the board within one year and whose companies were not acquired or about to be acquired by the next annual meeting (98 nominees).” Id. 
these companies was to induce changes in behavior and not necessarily to oust nominees from their board seats. ${ }^{71}$ For a shareholder who wants to induce a change in behavior but not a turnover in board composition, the voting decision under a plurality regime is an easy one. The voting decision under an MVR is more complicated. If a director or nominee faces a real risk of not receiving a majority of "for" votes, a decision to vote "against" may overshoot by inducing the director to leave the board. Under a majority regime, such a shareholder may therefore decide to cast a "for" vote (or abstain from voting) when, under a plurality regime, the shareholder would have voted against a nominee.

The four explanations we have discussed - the selection, deterrence or accountability, electioneering, and shareholder-restraint hypotheses-are not mutually exclusive. Each explanation may contribute to some extent to the difference in voting patterns. Moreover, different explanations may apply to different groups of firms. As noted above, majority voting has swept through the largest firms and has become increasingly common in smaller publicly traded companies. It is possible that majority voting, and perhaps corporate governance reforms more generally, will be adopted first by firms that are already very responsive to shareholders and thus can adopt the reform at very low cost-a selection effect. At some point, however, a reform may become accepted as a best practice, and later adopters may feel compelled to adopt the reform and become more responsive as a result-a causal effect. It is thus plausible that companies with shareholder-friendly governance adopted majority voting relatively early, but that companies that adopted majority voting later on do not differ much from nonadopters. Alternatively, it may also be plausible that reform advocates first pressured those companies with the least shareholder-friendly governance-those most in need of governance changes - to adopt majority voting. ${ }^{72}$ In the next Part, we describe various tests directed at examining the importance of each of these explanations for the sample as a whole and for different subsets of companies.

71 Id at $1423-24$.

72 Institutional investor CalPERS has a long-established practice of targeting underperforming firms with efforts at inducing corporate governance reform. See, for example, Mark Anson, Ted White, and Ho Ho, The Shareholder Wealth Effects of CalPERS' Focus List, 15 J App Corp Fin 102, 104-05 (Spring 2003) (examining the effectiveness of CalPERS's governance program). 


\section{EMPIRICAL ANALYSIS}

\section{A. Data Description}

We collected data on shareholder voting in director elections at S\&P 1500 companies for the years 2007 through 2013. Our data set consists of 64,933 elections, with about 9,000 observations per year. We obtained voting data on director elections at S\&P 1500 companies from ISS. We started with 65,751 observations of uncontested director elections in the data set. We dropped those observations in which the vote requirement was either unknown or not majority or plurality voting for the election of directors, leaving 65,690 observations. We then dropped observations involving entities other than corporations (such as real estate investment trusts), leaving 64,933 observations.

Our data include the votes cast "for" and "withhold" (or "against") 73 on each nominee, whether the election was governed by an MVR or a PVR, and the recommendation issued by ISS. We also collected information on several director and company characteristics that our past research has identified as associated with the vote outcome. ${ }^{74}$ We obtained executive compensation data from ExecuComp, stock return data from the Center for Research in Security Prices (CRSP), board composition and director biography data from RiskMetrics Group, institutional investor holdings data from Thomson Reuters, restatement data from Audit Analytics, issue-proposal outcome data from Georgeson, and state-of-incorporation data from Compustat. We also collected certain corporate governance data-including whether the company had an active poison pill, a classified board, or cumulative voting in the year of the election-from RiskMetrics. A description of the variables is in the Appendix.

For the data set as a whole, 37.3 percent of the elections were governed by majority voting, and ISS issued "withhold" recommendations for 6.6 percent of the nominees. The percentage of nominees with ISS "withhold" recommendations ("ISS WH Rec") peaked in 2009 at 12.3 percent and then declined to 4 percent by 2012 , while the percentage of directors subject to majority voting

\footnotetext{
73 "Withhold" votes are cast in elections under a PVR and "against" votes are cast in elections under an MVR.

74 See Choi, Fisch, and Kahan, 82 S Cal L Rev at 663-83, 696 (cited in note 18).
} 
climbed steadily from 14.8 percent in 2007 to 55.9 percent in 2013. ${ }^{75}$ These results are presented in Panel A of Table 2.76

Panel B provides summary statistics on the percentages of directors under a PVR or an MVR that received above specified cutoffs of "withhold" votes. For each cutoff, the difference between the likelihood that directors under a PVR would receive "withhold" votes above the cutoff was higher than the respective likelihood for directors under an MVR and the difference was significant at the 1 percent confidence level. However, the relative frequency gets starker the higher the level of "withhold" votes. For example, the likelihood of getting a majority "withhold" vote is 19 times higher for plurality than for majority vote companies, whereas the likelihood of getting a 10 percent "withhold" vote is only 1.7 times higher. Panel B also provides separate data on companies that had adopted majority voting by 2009 ("early adopters") and companies that subsequently adopted it ("late adopters").

Panel C provides summary statistics on the frequency of ISS "withhold" recommendations. As Panel C shows, nominees subject to an MVR are less likely to receive an ISS "withhold" recommendation than nominees subject to a PVR. The overall frequencies are 3.3 percent and 8.6 percent for majority voting and plurality voting, respectively, a difference that is statistically significant at the 1 percent confidence level. ${ }^{77}$ Moreover, in each year, the probability of receiving a negative ISS recommendation was lower for nominees subject to majority voting than for nominees subject to plurality voting. The difference between majority and plurality voting regimes is not significant for 2007 and 2008

75 We note that ISS "withhold" recommendations appear to have risen in response to the financial crisis of 2008 .

76 Our sample period includes the financial crisis of 2008. It is plausible that the events surrounding the financial crisis made issuers more responsive to demands for governance reform. See Stephen M. Bainbridge, Dodd-Frank: Quack Federal Corporate Governance Round II, 95 Minn L Rev 1779, 1782-83, 1786-88 (2011) (explaining how conditions surrounding the financial crisis created a climate that was conducive to governance reforms, including "quack" reforms). We note, however, that the pace of adoption appears fairly steady over the entire time period, as shown in Panel A of Table 2, rather than reflecting a concentration of firms that switched immediately following the crisis.

77 To assess statistical significance, we compute the difference between the frequencies for majority voting and plurality voting and the standard error of the difference clustered at the company level. See generally Vyacheslav Fos and Margarita Tsoutsoura, Shareholder Democracy in Play: Career Consequences of Proxy Contests, $114 \mathrm{~J}$ Fin Econ 316, 322 (2014) (comparing characteristics of board members using the standard error of the difference clustered at the company level). 
and is significant at the 1 percent confidence level for 2009 through $2013 .{ }^{78}$

TABle 2. PANel A: DiRector Nominees by Year, ISS RECOMMENDATION, AND VOTING RULE

\begin{tabular}{ccccccccc}
$\begin{array}{c}\text { Meeting } \\
\text { Year }\end{array}$ & $\begin{array}{c}\text { Number of } \\
\text { Director } \\
\text { Nominees }\end{array}$ & $\begin{array}{c}\text { \% of } \\
\text { Total }\end{array}$ & $\begin{array}{c}\text { Directors } \\
\text { with ISS } \\
\text { For Rec }\end{array}$ & $\begin{array}{c}\text { Directors } \\
\text { with ISS } \\
\text { WH Rec }\end{array}$ & $\begin{array}{c}\text { \% For } \\
\text { Rec }\end{array}$ & $\begin{array}{c}\text { Directors } \\
\text { under } \\
\text { PVR }\end{array}$ & $\begin{array}{c}\text { Directors } \\
\text { under } \\
\text { MVR }\end{array}$ & $\%$ MVR \\
\hline \hline 2007 & 8,250 & $12.7 \%$ & 7,717 & 533 & $93.5 \%$ & 7,031 & 1,219 & $14.8 \%$ \\
2008 & 8,607 & $13.3 \%$ & 8,056 & 551 & $93.6 \%$ & 6,733 & 1,874 & $21.8 \%$ \\
2009 & 9,061 & $14.0 \%$ & 7,951 & 1,110 & $87.7 \%$ & 6,493 & 2,568 & $28.3 \%$ \\
2010 & 9,486 & $14.6 \%$ & 8,657 & 829 & $91.3 \%$ & 6,211 & 3,275 & $34.5 \%$ \\
2011 & 9,689 & $14.9 \%$ & 9,257 & 432 & $95.5 \%$ & 5,094 & 4,595 & $47.4 \%$ \\
2012 & 9,813 & $15.1 \%$ & 9,421 & 392 & $96.0 \%$ & 4,753 & 5,060 & $51.6 \%$ \\
2013 & 10,027 & $15.4 \%$ & 9,586 & 441 & $95.6 \%$ & 4,418 & 5,609 & $55.9 \%$ \\
\hline \multirow{2}{*}{ Total: } & 64,933 & $100.0 \%$ & 60,645 & 4,288 & $93.4 \%$ & 40,733 & 24,200 & $37.3 \%$
\end{tabular}




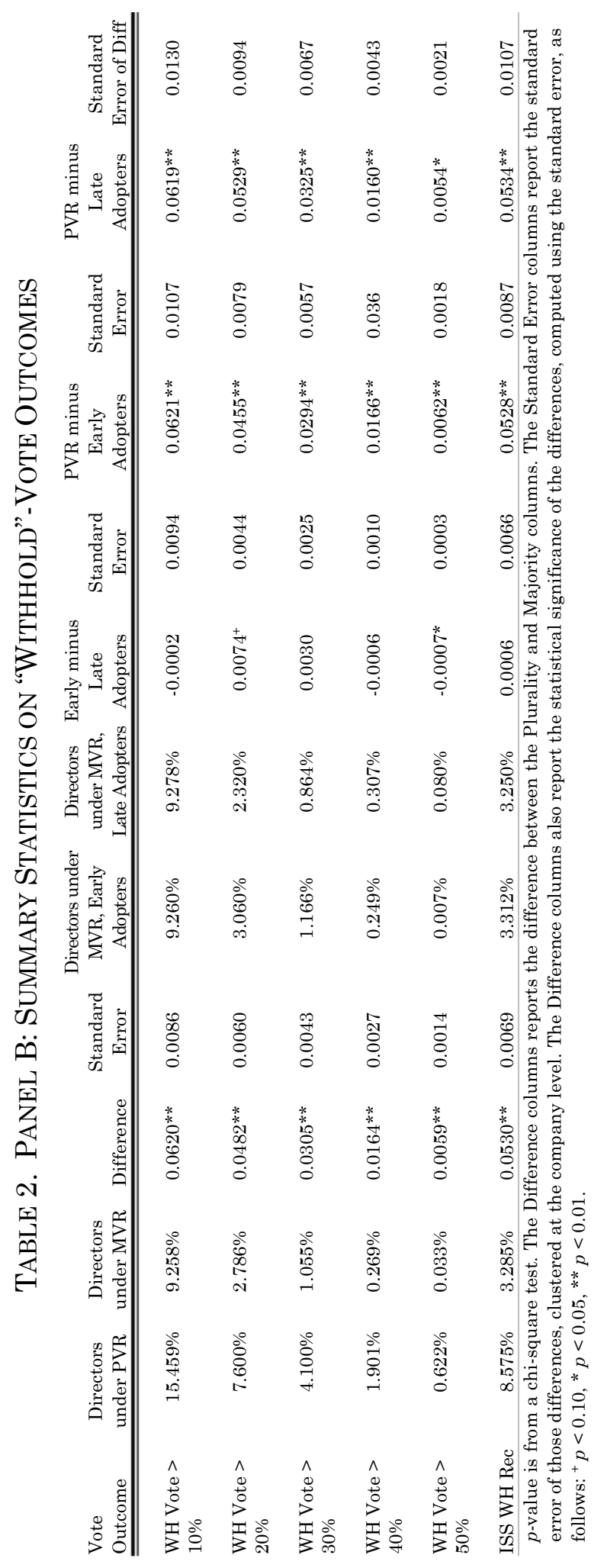




\section{TABle 2. PANEl C: PluRAlity Versus Majority Voting-ISS RECOMMENDATIONS PER YEAR}

\begin{tabular}{|c|c|c|c|c|c|c|c|c|c|c|}
\hline \multicolumn{4}{|c|}{ PVR Firms } & \multicolumn{3}{|c|}{ MVR Firms } & \multicolumn{2}{|c|}{$\begin{array}{c}\text { MVR Firms, } \\
\text { Early Adopters }\end{array}$} & \multicolumn{2}{|c|}{$\begin{array}{l}\text { MVR Firms, } \\
\text { Late Adopters }\end{array}$} \\
\hline Year & $\begin{array}{c}\text { Total } \\
\text { Directors }\end{array}$ & $\begin{array}{r}\text { Directors } \\
\text { with ISS } \\
\text { s WH Rec } \\
\end{array}$ & $\begin{array}{c}\% \mathrm{WH} \\
\operatorname{Rec}\end{array}$ & $\begin{array}{c}\text { Total } \\
\text { Directors }\end{array}$ & $\begin{array}{l}\text { Directors } \\
\text { with ISS } \\
\text { WH Rec }\end{array}$ & $\begin{array}{c}\% \\
\text { WH } \\
\text { Rec }\end{array}$ & $\begin{array}{l}\text { Directors } \\
\text { with ISS } \\
\text { WH Rec }\end{array}$ & $\begin{array}{c}\% \mathrm{WH} \\
\operatorname{Rec}\end{array}$ & $\begin{array}{l}\text { Directors } \\
\text { with ISS } \\
\text { WH Rec }\end{array}$ & $\begin{array}{c}\% \mathrm{WH} \\
\operatorname{Rec}\end{array}$ \\
\hline 2007 & 7,031 & 474 & $6.7 \%$ & 1,219 & 59 & $4.8 \%$ & 59 & $4.9 \%$ & - & - \\
\hline 2008 & 6,733 & 460 & $6.8 \%$ & 1,874 & 91 & $4.9 \%$ & 91 & $4.9 \%$ & - & - \\
\hline 2009 & 6,493 & 951 & $14.6 \%$ & 2,568 & 159 & $6.2 \%$ & 159 & $6.2 \%$ & - & - \\
\hline 2010 & 6,211 & 687 & $11.1 \%$ & 3,275 & 142 & $4.3 \%$ & 95 & $3.9 \%$ & 47 & $5.6 \%$ \\
\hline 2011 & 5,094 & 336 & $6.6 \%$ & 4,595 & 96 & $2.1 \%$ & 43 & $1.8 \%$ & 53 & $2.5 \%$ \\
\hline 2012 & 4,753 & 295 & $6.2 \%$ & 5,060 & 97 & $1.9 \%$ & 27 & $1.1 \%$ & 70 & $2.6 \%$ \\
\hline 2013 & 4,418 & 290 & $6.6 \%$ & 5,609 & 151 & $2.7 \%$ & 34 & $1.4 \%$ & 117 & $3.7 \%$ \\
\hline Total & 40,733 & 3,493 & $8.6 \%$ & 24,200 & 795 & $3.3 \%$ & 508 & $3.3 \%$ & 287 & $3.3 \%$ \\
\hline
\end{tabular}

\section{B. Data Analysis}

1. The selection hypothesis: Are companies that adopted majority voting different from those that did not?

As noted above, one problem with analyzing the effects of majority voting is that firms that adopt majority voting may be different from firms that do not. Consider, for example, a company that strives to have good corporate governance practices, as judged by ISS, the Council of Institutional Investors, and large mutual funds. As a result, none of its board members (other than the CEO) are employees or have business dealings with the company, its compensation committee employs exemplary procedures, its governance guidelines limit the number of board seats any director may have, and its directors have high attendance rates. Because corporate governance professionals at ISS ${ }^{79}$ and many institutions ${ }^{80}$ favor majority voting, the company has also adopted majority voting.

79 Institutional Shareholder Services Takes Stand on Majority Vote Standard: Current Director Election System Needs Reform (PR Newswire, Mar 11, 2005), archived at http://perma.cc/2YCY-8VJA (quoting Dr. Martha Carter, ISS's director of US research, as saying that "[a] majority vote standard transforms the director election process from a symbolic gesture to a meaningful voice for shareholders"); Deane, Majority Voting in Director Elections at *1 (cited in note 35 ).

80 The Council of Institutional Investors, in an August 11, 2011, letter to the Delaware State Bar Association's Section of Corporate Law, proposed amending the Delaware General Corporation Law to make majority voting the default setting: "The benefits of a majority vote standard are many: it democratizes the corporate electoral process; it puts real voting power in the hands of investors with minimal disruption to corporate affairs; 
For such a company, it is the company's underlying commitment to shareholder-friendly corporate governance (and presumably the reasons underlying that commitment, such as a committed board and CEO or fear of ISS) that caused both the lower prospect of high "withhold" votes and the adoption of majority voting.

To test for self-selection, we examined whether companies that adopted majority voting are different from those that did not. We compared companies that adopted majority voting in 2011, the year in our data set that saw the largest number of adoptions, with those that retained plurality voting. We then examined various measures of shareholder-friendly governance for the prior two years (2009 and 2010)_including the average percentage of "withhold" recommendations ("Avg ISS WH Rec Prior 2 Years"), whether the company's nominees had received any "withhold" recommendations ("Any ISS WH Rec Prior 2 Years"), the average percentage of "withhold" votes ("Avg WH Vote Prior 2 Years"), the highest "withhold" vote for any of the company's nominees ("High WH Vote Prior 2 Years"), and whether any nominee received a "withhold" vote above certain thresholds-both for companies that had switched to majority voting in 2011 and for companies that retained plurality voting in 2011 . The results are reported in Table 3.

As Table 3 shows, companies that switched to majority voting in 2011 had a different prior record than companies that retained plurality voting. In the two years prior to the switch, companies that switched in 2011 had a significantly lower percentage of nominees who received a "withhold" recommendation (10.1 percent versus 15.3 percent), a significantly lower likelihood that at least one nominee would receive a "withhold" recommendation (32.9 percent versus 41.8 percent), and a significantly lower likelihood of having a nominee receive a "withhold" vote of at least 30 percent (18.0 percent versus 25.2 percent).

The results reported in Table 3 support the selection hypothesis. They indicate that companies whose nominees receive less ISS support and experience less electoral success are overall less likely to adopt majority voting. To the extent that electoral success in subsequent years is correlated with ISS support and electoral

and it makes boards[] more representative of, and accountable to, shareowners." Jeff Mahoney, General Counsel of the Council of Institutional Investors, Letter to Frederick H. Alexander, Chair of the Delaware State Bar Association's Section of Corporate Law *3 (Aug 11, 2011), archived at http://perma.cc/SVQ9-DVWX. 
TABLE 3. ISS WITHHOLD RECOMMENDATIONS AND WITHHOLD Vote OUTCOMES FOR THE PRIOR TWO YEARS

\begin{tabular}{|c|c|c|c|c|c|}
\hline \multirow[t]{2}{*}{ Variable } & \multicolumn{2}{|c|}{$\begin{array}{l}\text { Did Not } \\
\text { Switch }\end{array}$} & \multicolumn{2}{|c|}{$\begin{array}{c}\text { Switched to } \\
\text { MVR } \\
\end{array}$} & \multirow[b]{2}{*}{$\mathrm{p}$-value } \\
\hline & $\mathrm{N}$ & Mean & $\mathrm{N}$ & Mean & \\
\hline Avg ISS WH Rec Prior 2 Years & 827 & 0.153 & 167 & 0.101 & 0.011 \\
\hline Any ISS WH Rec Prior 2 Years & 827 & 0.418 & 167 & 0.329 & 0.032 \\
\hline Avg WH Vote Prior 2 Years & 826 & 0.080 & 167 & 0.066 & 0.052 \\
\hline High WH Vote Prior 2 Years & 826 & 0.189 & 167 & 0.168 & 0.125 \\
\hline $\begin{array}{l}\text { Any Director Received }>20 \% \mathrm{WH} \\
\text { Vote Prior } 2 \text { Years }\end{array}$ & 826 & 0.381 & 167 & 0.317 & 0.119 \\
\hline $\begin{array}{l}\text { Any Director Received }>30 \% \mathrm{WH} \\
\text { Vote Prior } 2 \text { Years }\end{array}$ & 826 & 0.252 & 167 & 0.180 & 0.046 \\
\hline $\begin{array}{l}\text { Any Director Received }>40 \% \mathrm{WH} \\
\text { Vote Prior } 2 \text { Years }\end{array}$ & 826 & 0.138 & 167 & 0.102 & 0.208 \\
\hline $\begin{array}{l}\text { Any Director Received }>50 \% \mathrm{WH} \\
\text { Vote Prior } 2 \text { Years }\end{array}$ & 826 & 0.052 & 167 & 0.048 & 0.825 \\
\hline
\end{tabular}

success in prior years, this self-selection would explain at least part of the reason why nominees in companies with majority voting fare better than nominees in companies with plurality voting. We note that our prior research has found a strong association between an ISS "withhold" recommendation and the percentage of "withhold" votes. ${ }^{81}$

To explore the self-selection hypothesis in greater detail, we estimated a Cox proportional hazards model for the adoption of majority voting during the 2007 to 2012 period. The Cox proportional hazards model is a type of statistical survival model that relates the time to a specified event (in our case, the adoption of majority voting) to various independent variables that may affect the amount of time to the event (such as the fraction of shares that are held by institutional investors). The dependent variable in the Cox proportional hazards model is a switch from a PVR to an MVR. The hazards model initially includes all firms that used

81 See, for example, Choi, Fisch, and Kahan, 3 Harv Bus L Rev at 64 (cited in note 28) (finding that "an ISS 'withhold' recommendation is a significant factor in predicting a high 'withhold' vote"). 
plurality voting for the election of directors in 2007. As firms switch to majority voting, they drop out of the regression analysis. The hazards model is consistent with the fact that many firms move from plurality to majority voting, but few if any move back to plurality voting once they have switched to majority voting.

We include as an independent variable in each model either the mean of the percentage of ISS "withhold" recommendations for the prior two years (Avg ISS WH Rec Prior 2 Years); an indicator variable for whether any of the director nominees at a firm received an ISS "withhold" recommendation in the prior two years (Any ISS WH Rec Prior 2 Years); or the highest "withhold" vote for any director nominee at a firm in the prior two years (High WH Vote Prior 2 Years). Also, in all three models we included two additional variables: whether the firm has a standing poison pill ("PPill") and whether the firm has a classified board ("ClassBd"). ${ }^{82}$ Because both poison pills and classified boards are frowned upon by governance activists, their presence may indicate that the firm has less shareholder-friendly governance. A finding that firms with a poison pill or with a classified board are less likely to adopt majority voting would thus be consistent with the selection hypothesis.

As controls, we included an indicator variable for whether the firm is incorporated in Delaware ("Delaware"); a variable for whether the firm uses cumulative voting ("CumVote") (the MVR is not well-defined for firms using cumulative voting); two indicator variables for whether the firm was in the top 5 percent or bottom 5 percent of the companies in our sample based on the abnormal return for the one-year period prior to the annual meeting ("Top5AbRet" and "Bot5AbRet") (firms with better stock performance may be better able to resist pressure to adopt majority voting on the rationale of "never change a winning team"); the logarithm of the market capitalization of the company ("ln(Mktcap)") (reflecting the greater propensity of larger firms to adopt majority voting); 83 a variable for the percentage of shares held by institutional investors ("Insthold"); and a variable for whether a charter

82 Our prior research has indicated that, while the presence of a poison pill is not significantly associated with the electoral success of a firm's nominees, the presence of a classified board is. See Choi, Fisch, and Kahan, 59 Emory L J at 893-94 (cited in note 27).

83 We posit that the relationship between market capitalization and the adoption of majority voting is nonlinear, with accelerating adoption at the higher levels of market capitalization. We use a logarithm of market capitalization transformation to capture this nonlinearity in the relationship. As a robustness test, we reestimated the models of Table 4 with the inclusion of the nontransformed market capitalization instead of the 
amendment is required to adopt majority voting ("CharterAmend") (making such adoption harder). We note that our prior research indicated that company size is negatively associated with the percentage of "withhold" votes a nominee receives. ${ }^{84}$ To that extent, the size variable may also pick up some selection effect. The size variable may also reflect the potential pressure on the company to adopt majority voting because larger issuers may receive more media attention or greater governance pressure from institutional investors. ${ }^{85}$

In the Cox proportional hazards model, a coefficient estimate of less than one indicates that the variable is associated with a reduced likelihood of the adoption of majority voting, and a coefficient estimate of more than one indicates that the variable is associated with an increased likelihood of the adoption of majority voting. The $z$-statistics reported in Table 4 relate to whether the coefficient is different from one.

The results are reported in Table 4, Models 1 to 3 . They indicate that having a prior record of ISS "withhold" recommendations is negatively associated with the adoption of majority voting. That is, a company whose nominees receive ISS "withhold" recommendations is less likely to adopt majority voting, as the selection hypothesis predicts. For example, Model 2 indicates that companies that had at least one ISS "withhold" recommendation in the past two years were, on average, 18.2 percent less likely to adopt majority voting than companies that had no ISS "withhold" recommendations, a decline that is statistically significant at the 5 percent level. In addition, in Models 2 and 3, the presence of a poison pill is associated with a significantly lower likelihood (at the 10 percent level) of adopting majority voting. We do not find, however, that low "withhold" votes for directors in prior years or the absence of a classified board (both evidence of shareholder responsiveness)

\footnotetext{
logarithm of market capitalization as an independent variable. Unreported, we obtained the same qualitative results as in Table 4.

84 See Choi, Fisch, and Kahan, 59 Emory L J at 893, 913 (cited in note 27).

85 The Cox proportional hazards model we estimate in Table 4 is as follows: $\mathrm{h}(\mathrm{t}, \mathbf{x})=\mathrm{h}_{0}(\mathrm{t}) \mathrm{e}^{\mathrm{x}^{\prime} \beta}$

In the Cox proportional hazards model, $\mathrm{h}(\mathrm{t}, \mathbf{x})$ is the hazard rate, $\mathbf{x}$ is the vector of regressors, and $\beta$ is the vector of estimated coefficients. For Model 1 of Table 4, we include in the vector of regressors the following: Avg ISS WH Rec Prior 2 Years, Delaware, PPill, ClassBd, CumVote, Top5AbRet, Bot5AbRet, $\ln ($ Mktcap), Insthold, and CharterAmend. The other models of Table 4 follow the same basic model with variations as noted in Table 4 and the text.
} 
TABLE 4. HAZARDS MODEL FOR SWITCH TO MAJORITY VOTING REGIME

\begin{tabular}{|c|c|c|c|c|c|c|c|c|c|}
\hline & Model 1 & Model 2 & Model 3 & Model 4 & Model 5 & Model 6 & Model 7 & Model 8 & Model 9 \\
\hline & $\begin{array}{c}\text { Avg ISS } \\
\text { WH Rec } \\
\text { Prior } 2 \\
\text { Years } \\
\text { Whole } \\
\text { Sample }\end{array}$ & $\begin{array}{c}\text { Any ISS } \\
\text { WH Rec } \\
\text { Prior } 2 \\
\text { Years } \\
\text { Whole } \\
\text { Sample }\end{array}$ & $\begin{array}{c}\text { High WH } \\
\text { Vote } \\
\text { Prior } 2 \\
\text { Years } \\
\text { Whole } \\
\text { Sample }\end{array}$ & $\begin{array}{l}\text { Avg ISS } \\
\text { WH Rec } \\
\text { Prior } 2 \\
\text { Years } \\
\text { Early } \\
\text { Adopters }\end{array}$ & $\begin{array}{l}\text { Any ISS } \\
\text { WH Rec } \\
\text { Prior } 2 \\
\text { Years } \\
\text { Early } \\
\text { Adopters }\end{array}$ & $\begin{array}{c}\text { High } \\
\text { WH Vote } \\
\text { Prior } 2 \\
\text { Years } \\
\text { Early } \\
\text { Adopters }\end{array}$ & $\begin{array}{c}\text { Avg ISS } \\
\text { WH Rec } \\
\text { Prior } 2 \\
\text { Years } \\
\text { Late } \\
\text { Adopters }\end{array}$ & $\begin{array}{l}\text { Any ISS } \\
\text { WH Rec } \\
\text { Prior } 2 \\
\text { Years } \\
\text { Late } \\
\text { Adopters }\end{array}$ & $\begin{array}{c}\text { High WH } \\
\text { Vote Prior } \\
2 \text { Years } \\
\text { Late } \\
\text { Adopters }\end{array}$ \\
\hline $\begin{array}{l}\text { Avg ISS WH } \\
\text { Rec Prior } 2 \\
\text { Years }\end{array}$ & $\begin{array}{l}0.628^{+} \\
(-1.74)\end{array}$ & & & $\begin{array}{l}0.440^{+} \\
(-1.69)\end{array}$ & & & $\begin{array}{l}0.693 \\
(-1.12)\end{array}$ & & \\
\hline $\begin{array}{l}\text { Any ISS WH } \\
\text { Rec Prior } 2 \\
\text { Years }\end{array}$ & & $\begin{array}{l}0.818^{*} \\
(-2.08)\end{array}$ & & & $\begin{array}{l}0.736^{*} \\
(-2.16)\end{array}$ & & & $\begin{array}{l}0.870 \\
(-1.04)\end{array}$ & \\
\hline $\begin{array}{l}\text { High WH Vote } \\
\text { Prior } 2 \text { Years }\end{array}$ & & & $\begin{array}{l}0.869 \\
(-0.44)\end{array}$ & & & $\begin{array}{l}0.566 \\
(-1.13)\end{array}$ & & & $\begin{array}{l}1.075 \\
(0.17)\end{array}$ \\
\hline Delaware & $\begin{array}{l}1.240^{*} \\
(2.10)\end{array}$ & $\begin{array}{l}1.246^{*} \\
(2.15)\end{array}$ & $\begin{array}{l}1.250^{*} \\
(2.18)\end{array}$ & $\begin{array}{l}1.627^{* *} \\
(3.30)\end{array}$ & $\begin{array}{l}1.641^{* * *} \\
(3.36)\end{array}$ & $\begin{array}{l}1.648^{* * *} \\
(3.39)\end{array}$ & $\begin{array}{l}0.906 \\
(-0.67)\end{array}$ & $\begin{array}{l}0.909 \\
(-0.65)\end{array}$ & $\begin{array}{l}0.913 \\
(-0.63)\end{array}$ \\
\hline PPill & $\begin{array}{l}0.844 \\
(-1.54)\end{array}$ & $\begin{array}{l}0.835^{+} \\
(-1.65)\end{array}$ & $\begin{array}{l}0.827^{+} \\
(-1.72)\end{array}$ & $\begin{array}{l}0.725^{*} \\
(-2.21)\end{array}$ & $\begin{array}{l}0.717^{*} \\
(-2.28)\end{array}$ & $\begin{array}{l}0.718^{*} \\
(-2.27)\end{array}$ & $\begin{array}{l}1.023 \\
(0.13)\end{array}$ & $\begin{array}{l}1.004 \\
(0.02)\end{array}$ & $\begin{array}{l}0.981 \\
(-0.11)\end{array}$ \\
\hline ClassBd & $\begin{array}{l}1.023 \\
(0.24)\end{array}$ & $\begin{array}{l}1.003 \\
(0.04)\end{array}$ & $\begin{array}{l}1.015 \\
(0.16)\end{array}$ & $\begin{array}{l}1.087 \\
(0.65)\end{array}$ & $\begin{array}{l}1.059 \\
(0.45)\end{array}$ & $\begin{array}{l}1.066 \\
(0.50)\end{array}$ & $\begin{array}{l}0.983 \\
(-0.13)\end{array}$ & $\begin{array}{l}0.968 \\
(-0.25)\end{array}$ & $\begin{array}{l}0.976 \\
(-0.18)\end{array}$ \\
\hline CumVote & $\begin{array}{l}0.592^{*} \\
(-2.44)\end{array}$ & $\begin{array}{l}0.589^{*} \\
(-2.46)\end{array}$ & $\begin{array}{l}0.588^{*} \\
(-2.47)\end{array}$ & $\begin{array}{l}0.551^{+} \\
(-1.84)\end{array}$ & $\begin{array}{l}0.548^{+} \\
(-1.85)\end{array}$ & $\begin{array}{l}0.541^{+} \\
(-1.89)\end{array}$ & $\begin{array}{l}0.631 \\
(-1.60)\end{array}$ & $\begin{array}{l}0.628 \\
(-1.61)\end{array}$ & $\begin{array}{l}0.632 \\
(-1.59)\end{array}$ \\
\hline Top5AbRet & $\begin{array}{l}0.529^{* *} \\
(-2.64)\end{array}$ & $\begin{array}{l}0.528^{* *} \\
(-2.65)\end{array}$ & $\begin{array}{l}0.530^{* *} \\
(-2.63)\end{array}$ & $\begin{array}{l}0.683 \\
(-1.23)\end{array}$ & $\begin{array}{l}0.689 \\
(-1.20)\end{array}$ & $\begin{array}{l}0.686 \\
(-1.21)\end{array}$ & $\begin{array}{l}0.389^{*} \\
(-2.45)\end{array}$ & $\begin{array}{l}0.386^{*} \\
(-2.47)\end{array}$ & $\begin{array}{l}0.389^{*} \\
(-2.45)\end{array}$ \\
\hline Bot5AbRet & $\begin{array}{l}1.415 \\
(1.50)\end{array}$ & $\begin{array}{l}1.433 \\
(1.55)\end{array}$ & $\begin{array}{l}1.418 \\
(1.51)\end{array}$ & $\begin{array}{l}1.564 \\
(1.36)\end{array}$ & $\begin{array}{l}1.583 \\
(1.40)\end{array}$ & $\begin{array}{l}1.559 \\
(1.35)\end{array}$ & $\begin{array}{l}1.277 \\
(0.75)\end{array}$ & $\begin{array}{l}1.295 \\
(0.79)\end{array}$ & $\begin{array}{l}1.277 \\
(0.75)\end{array}$ \\
\hline $\ln$ (Mktcap) & $\begin{array}{l}1.596^{* *} \\
(15.19)\end{array}$ & $\begin{array}{l}1.600^{* * *} \\
(15.26)\end{array}$ & $\begin{array}{l}1.592^{* *} \\
(15.12)\end{array}$ & $\begin{array}{l}1.627^{* *} \\
(11.61)\end{array}$ & $\begin{array}{l}1.637^{* * *} \\
(11.70)\end{array}$ & $\begin{array}{l}1.620^{* * *} \\
(11.50)\end{array}$ & $\begin{array}{l}1.545^{* *} \\
(9.29)\end{array}$ & $\begin{array}{l}1.546^{* *} \\
(9.33)\end{array}$ & $\begin{array}{l}1.547^{* *} \\
(9.35)\end{array}$ \\
\hline Insthold & $\begin{array}{l}1.699^{+} \\
(1.86)\end{array}$ & $\begin{array}{l}1.671^{+} \\
(1.80)\end{array}$ & $\begin{array}{l}1.716^{+} \\
(1.90)\end{array}$ & $\begin{array}{l}1.442 \\
(0.97)\end{array}$ & $\begin{array}{l}1.393 \\
(0.87)\end{array}$ & $\begin{array}{l}1.468 \\
(1.01)\end{array}$ & $\begin{array}{l}2.258^{+} \\
(1.85)\end{array}$ & $\begin{array}{l}2.258^{+} \\
(1.85)\end{array}$ & $\begin{array}{l}2.299^{+} \\
(1.88)\end{array}$ \\
\hline CharterAmend & $\begin{array}{l}0.654^{*} \\
(-2.54)\end{array}$ & $\begin{array}{l}0.649^{* * *} \\
(-2.58)\end{array}$ & $\begin{array}{l}0.653^{*} \\
(-2.54)\end{array}$ & $\begin{array}{l}0.573^{*} \\
(-2.08)\end{array}$ & $\begin{array}{l}0.564^{*} \\
(-2.13)\end{array}$ & $\begin{array}{l}0.573^{*} \\
(-2.07)\end{array}$ & $\begin{array}{l}0.694^{+} \\
(-1.70)\end{array}$ & $\begin{array}{l}0.690^{+} \\
(-1.72)\end{array}$ & $\begin{array}{l}0.687^{+} \\
(-1.74)\end{array}$ \\
\hline$N$ & 4693 & 4693 & 4668 & 2801 & 2801 & 2779 & 1892 & 1892 & 1889 \\
\hline Pseudo $R^{2}$ & 0.042 & 0.042 & 0.041 & 0.055 & 0.056 & 0.054 & 0.031 & 0.030 & 0.030 \\
\hline Log Likelihood & -3505.9 & -3505.3 & -3505.8 & -1882.6 & -1881.8 & -1882.2 & -1611.7 & -1611.8 & -1612.0 \\
\hline
\end{tabular}

correlate with an increased likelihood of a switch to majority voting. As predicted, larger companies and companies with a larger percentage of institutional investors are more likely to adopt majority voting. Companies with cumulative voting are less likely to do so. ${ }^{86}$

86 We would predict that companies with a controlling shareholder are less likely to adopt majority voting. We did not control for the presence of a controlling shareholder, in 
We examine two additional selection factors that are not directly related to corporate governance. First, we compare companies that are required to adopt majority voting through a charter amendment to those that can adopt it through a bylaw. As noted above, most states provide for plurality voting as the default rule but authorize individual firms to opt in to majority voting. In some states, majority voting must be provided for in the charter; in others (including Delaware), majority voting may be implemented through either a charter or bylaw amendment. Amending the corporate charter is more difficult than a bylaw amendment and typically requires both board approval and a shareholder vote. ${ }^{87}$ In Models 1 through 3, the coefficient on CharterAmend is less than one and is significant at either the 5 percent or 1 percent level. Unsurprisingly, we find that the mechanism of adoption affects the likelihood that firms will adopt majority voting; firms that can adopt majority voting only via a charter amendment are less likely to do so.

Second, we consider the extent to which the decision to adopt majority voting may be tied to firm performance. There are two possibilities. Better-performing firms may have more shareholderoriented governance, in which case we might see a correlation between performance and adoption of an MVR. Alternatively, shareholders might seek greater accountability from the boards of firms that perform less well, so that a high return insulates a company from the pressure to adopt majority voting. Our findings are consistent with the latter explanation. For companies in the top 5 percent of abnormal stock price returns in the year before the annual meeting (Top5AbRet), the likelihood of adopting majority voting is only about half as high as it is for companies in the base category of comparison that are neither Top5AbRet nor Bot5AbRet (that is, those companies in the middle, with returns

part because the universe of such companies includes some companies with a substantial nonmajority shareholder as well as some in which shareholders exercise control through dual-class stock. See Clifford G. Holderness, The Myth of Diffuse Ownership in the United States, 22 Rev Fin Stud 1377, 1379-85 (2009) (describing the prevalence of substantial block-holders among US corporations). We note that the percentage of S\&P 1500 issuers with a controlling shareholder during the time period of our study was approximately 7 percent, including issuers in which control was exercised through dual-class stock. See Sean Quinn, Controlled Companies in the S\&P 1500: Performance and Risk Review (Harvard Law School Forum on Corporate Governance and Financial Regulation, Oct 25, 2012), archived at http://perma.cc/7737-3ZQR.

87 See Siegel, 2011 Colum Bus L Rev at 370-71 (cited in note 20) (noting that out of twenty-four states that require a charter amendment to change the voting procedure, twenty-one require both board and shareholder approval). 
ranging from the 5 th percentile up to the 95 th percentile in the distribution of returns).

The analysis becomes particularly interesting when we differentiate between early and late adopters. We reestimated Models 1 through 3 of Table 4 for only the years from 2007 to 2009 and report these models as Models 4 through 6 of Table 4 (the early-adopter hazards models). We also reestimated Models 1 through 3 of Table 4 for those firms that were plurality voting firms in 2009 for the years from 2010 to 2012 and report these models as Models 7 through 9 of Table 4 (the late-adopter hazards models). As with the full sample, we find that the prior record of ISS "withhold" recommendations and the presence of a poison pill are negatively associated with the adoption of majority voting by early adopters. The effect is also economically significant. For example, in Model 5, the point estimates indicate that, during the early adoption period (2007 to 2009), having received an ISS "withhold" recommendation for any director in the last two years reduced the likelihood of adopting majority voting by 26.4 percent, and having a poison pill reduced the likelihood by 28.3 percent. By contrast, the variable for positive abnormal returns (which we interpret as a measure of either pressure to adopt majority voting or the board's ability to resist such pressure) is insignificant.

For late adopters, by contrast, the variables that were significant for the full sample and that we took as indicators of shareholder responsiveness - the prior record of ISS "withhold" recommendations and the presence of a poison pill-are now insignificant. By contrast, the variable that may reflect reduced outside pressure to adopt majority voting or the ability to resist such pressure-positive abnormal returns-is significant, which is consistent with lower pressure or a higher ability to resist pressure making the adoption of majority voting less likely. ${ }^{8} 8$

In conclusion, we find some evidence consistent with early adopters of majority voting differing from those that retain a plurality standard: companies are more likely to adopt majority voting if they do not perceive their existing board members as being at risk of receiving an ISS "withhold" recommendation, or if they are generally more responsive to shareholder concerns (as proxied

88 Of course, strong performance does not guarantee that shareholders will not seek to have the company adopt majority voting. See, for example, Barry B. Burr, Apple to Implement CalPERS Majority-Voting Proposal (Pensions \& Investments, Feb 23, 2012), archived at http://perma.cc/99AD-3G2C (describing Apple's decision to adopt majority voting in response to efforts by CalPERS). 
by the absence of a poison pill). We find no statistically significant evidence among early adopters that the ability to resist pressure is related to the adoption of majority voting. The evidence is consistent with the notion that early adopters adopt majority voting voluntarily because they believe that it reflects the principles of shareholder-friendly governance to which they already subscribe, and not due to outside pressure.

For late adopters, we find no statistically significant evidence of similar self-selection. In particular, we are unable to reject the hypothesis that late adopters do not differ from nonadopters in their prior electoral and ISS records. Late adopters, however, are less likely to have experienced abnormally positive stock price performance prior to adoption than nonadopters, which may have increased the outside pressure to make governance changes.

There is one caveat to our results. The lack of a statistically significant relationship for late adopters between the prior ISS record and the decision to switch to majority voting may be due to greater variance in the relationship. Despite this greater variance, it is possible that the average effect of the prior ISS record on the decision to switch to majority voting is similar for early and late adopters. ${ }^{89}$ The greater variance is nonetheless consistent with at least some late adopters adopting majority voting only semivoluntarily (that is, even if they have a poor prior ISS record) compared with early adopters.

A plausible interpretation of these results is that shareholder activists first pushed for the adoption of an MVR at firms where an MVR may have been largely costless (or at least low-cost) because these firms were already responsive to shareholders. As time went by and MVRs became accepted as a best practice, firms for whom

\footnotetext{
89 As a robustness test, we reestimated Model 1 of Table 4 for the whole sample, dividing Avg ISS WH Rec Prior 2 Years into an early version (for 2007 to 2009) and a late version (for 2010 to 2012). We reestimated Models 2 and 3 of Table 4 for the whole sample using early and late versions of Any ISS WH Rec Prior 2 Years and High WH Vote Prior 2 Years, respectively, in each model. Unreported, we obtained the same qualitative results as in Models 4 through 9 of Table 4. The coefficients on the early versions of the Avg ISS WH Rec Prior 2 Years and Any ISS WH Rec Prior 2 Years variables were significantly different from zero (at the 10 percent and 5 percent levels, respectively). The coefficients on the late version of the Avg ISS WH Rec Prior 2 Years and Any ISS WH Rec Prior 2 Years variables were not significant. An $F$-test of the differences between the early and late versions of Any ISS WH Rec Prior 2 Years and High WH Vote Prior 2 Years, nonetheless, showed that the differences were not statistically significant. The coefficients on the early and late versions of High WH Vote Prior 2 Years were not significantly different from zero.
} 
an MVR was more costly-because they were less shareholder responsive-began to adopt it as well. Shareholder activists instead could have first targeted the least shareholder-responsive firms with their MVR campaigns as a way of improving the governance of the firms that, in their eyes, needed it most, ignoring the firms that were already responsive. This is inconsistent with our finding that the early adopters were most shareholder responsive, and thus does not seem to have been what happened.

2. The causation hypothesis: the effects of majority voting on subsequent electoral success.

One way to distinguish between selection and causation is to examine a particular firm both before and after the adoption of majority voting. To the extent that a firm that adopted an MVR had shareholder-friendly governance prior to adoption and maintained it throughout the measurement period, any changes in the actions of the firm and the level of voting support are not attributable to self-selection. If, however, the adoption of MVR changed director responsiveness to shareholders, increased the level of electioneering, or generated greater shareholder self-restraint, we would expect to see a reduction in "withhold" votes after the adoption of majority voting.

To test this possibility, we ran a set of ordinary least squares regressions on company-director-level data including firm-fixed effects. By including firm-fixed effects, we compare the record of each company after the adoption of majority voting to the firm's own record prior to the adoption, after controlling for other factors. In particular, by including year-fixed effects, we also control for secular time trends. As dependent variables, we initially use an indicator variable for whether a specific director received a "withhold" vote of 30 percent or more ("Whvote30"). 90 A 30 percent "withhold" vote is a sign of serious shareholder dissatisfaction. ${ }^{91}$

90 We chose 30 percent, rather than 50 percent, as a threshold because of the small number of elections in which a nominee received a majority "withhold" vote. We have also observed elsewhere that commentators consider "withhold" votes substantial at well under 50 percent. See Choi, Fisch, and Kahan, 3 Harv Bus L Rev at 63 n 113 (cited in note 28) (collecting sources).

91 See Ron Orol, Attack of the Zombie Director: A Look at Directors Who Stay on Boards Though Shareholders Oppose Them Year after Year (The Deal, Aug 6, 2015), archived at http://perma.cc/S7RY-VBWG ("Most governance observers contend that even a $30 \%$ no vote demonstrates a sufficient level of shareholder discontent warranting a company's response."); Choi, Fisch, and Kahan, 3 Harv Bus L Rev at 63 (cited in note 28) (defining “a high 'withhold' vote as a 'withhold' vote of $30 \%$ or more of the votes cast”). 
In robustness checks, we repeat our analysis with different thresholds.

Our key independent variable of interest is the variable "MVR," which takes the value of one if the nominee is elected under an MVR and zero otherwise. The causation hypothesis predicts a negative coefficient for the MVR variable. We included as controls year-fixed effects and several variables that our prior research indicated may affect ISS recommendations or the percentage of "withhold" votes. ${ }^{92}$ These included a variable for the percentage of shares held by institutional investors (Insthold); whether the CEO of the company was in the top 5 percent of total excess compensation ("Top5AbComp"); the natural logarithm of the market capitalization of the company (ln(Mktcap)) (reflecting the greater propensity of larger firms to adopt majority voting); the standard deviation in the company's stock return measured for the one-year period prior to the annual meeting ("SDret"); and two indicator variables for whether the firm was in the top 5 percent or bottom 5 percent of companies in our sample based on the abnormal holding period return for the one-year period prior to the annual meeting (Top5AbRet and Bot5AbRet). ${ }^{93}$

Model 1 includes observations for all years. Model 2 excludes observations for the two years following the adoption of a shareholder resolution calling for majority voting. Model 2 thus accounts for the possibility that shareholders may "punish" directors for a failure to implement majority voting-or "reward" them for implementing majority voting-following the adoption of such a resolution. Model 3 excludes, in addition, observations for the first year in which a company employed majority voting (regardless of whether there was a shareholder resolution), reasoning again that shareholders may "reward" these companies, resulting in an unusually low likelihood of a 30 percent "withhold" vote. Model 4 includes observations from only firms that eventually adopted majority voting. The results are reported in Panel A of Table 5.

\footnotetext{
92 See Choi, Fisch, and Kahan, 82 S Cal L Rev at 671-72 (cited in note 18).

93 We estimate Model 1 in Panel A of Table 5 using ordinary least squares with errors clustered by company as follows:

Whvote $30_{i}=\alpha+\beta_{1 i}$ MVR $_{i}+\beta_{2 i}$ Insthold $_{i}$

$+\beta_{3 i}$ Top AbComp $p_{i}+\beta_{4 i} \ln (\text { Mktcap })_{i}$

$+\beta_{5 \mathrm{i}}$ SDret $_{\mathrm{i}}+\beta_{6 \mathrm{i}}$ Top5AbRet $_{\mathrm{i}}$

$+\beta_{7_{\mathrm{i}} \text { Bot} \text { AbRet }_{i}}+$ Firm Effects + Year Effect $+\varepsilon_{\mathrm{i}}$

The other models of Panels A through $\mathrm{C}$ of Table 5 follow the same basic model with variations as noted in Table 5 and the text.
} 
The results of these regressions lend support to the hypothesis that adoption of majority voting induced some change in behavior. After a company adopts an MVR, the likelihood that a nominee of that company will receive a "withhold" vote in excess of 30 percent drops by 2 to 3 percentage points relative to when the company was under a PVR, a decline that is statistically significant. ${ }^{94}$ The results are robust to the exclusion of observations for the two years following the approval of a shareholder resolution calling for majority voting (Model 2), to the further exclusion of observations for the first year in which a company employed majority voting (Model 3), and to the exclusion of observations from firms that never adopted majority voting (Model 4).

Because the regressions employ firm-fixed effects, self-selection would not explain the results if the exogenous probability that a company nominee would attract a high "withhold" vote is stable over time for each company. However, the possibility exists that a firm suffered from an exogenous shock that decreased that probability and, due to that shock, also decided to adopt majority voting. To address this possibility, we ran a separate regression including observations from only firms that adopted majority voting after shareholders adopted a proposal calling for the institution of majority voting (Model 5). These firms adopted majority voting under significant pressure, rather than by choice. We again find a statistically significant decrease in the probability that a nominee of that company will receive a "withhold" vote in excess of 30 percent relative to when the company was under plurality voting.

We ran the regressions (with the full set of observations) using thresholds of 10 percent, 20 percent, 40 percent, and 50 percent, reported in Models 6 through 9 of Panel A of Table 5, and also obtained statistically significant results. ${ }^{95}$ We note, however,

\footnotetext{
94 As a robustness test, we estimated Model 1 in Panel A of Table 5 without firmfixed effects. We obtained the same qualitative results as in Model 1. In particular, the coefficient on MVR remained negative and is significant at the 1 percent level (and of similar magnitude as the coefficient in Model 1). We also estimated Model 1 in Panel A of Table 5 with firm-fixed effects but without any control variables. The coefficient on MVR remained negative and is significant at the 1 percent level (and of similar magnitude as the coefficient in Model 1).

95 The coefficient on MVR in our models in Panel A of Table 5 with firm-fixed effects represents an average effect of majority voting for all directors. It may be that the shift to majority voting did in fact result in a greater "withhold" vote for some directors-but this effect is muted by the same amount of, or more, votes for other directors after the shift to majority voting. We compared the standard deviation of the percentage of "withhold" votes and the incidence of Whvote30 for the directors at the same company both prior to and after the shift to an MVR. If some directors received more "withhold" votes but others in
} 
that the coefficients for MVR in the regressions using a 10 percent and a 20 percent cutoff are close to the coefficient for MVR in the regression using a 30 percent cutoff. In these regressions, the MVR coefficients represent the change in the likelihood of receiving a "withhold" vote above the threshold. Thus, for example, the likelihood of receiving a "withhold" vote above 30 percent, after controlling for firm-fixed effects and other factors, declines by 2.59 percentage points after a company adopts an MVR (as reported in Model 1). The likelihood of receiving a "withhold" vote above 10 percent declines by 3.17 percentage points after a company adopts an MVR (as reported in Model 6). The similarity in coefficients suggests that there is not a significant change in the likelihood of receiving a "withhold" vote between 10 percent and 30 percent and that the results in the regressions using these thresholds are driven by the reduced likelihood of a "withhold" vote in excess of 30 percent. We explore this further below.

We next differentiated between early adopters and late adopters of majority voting for each model in Panel A by including separate dummy variables for each set of firms ("EarlyMVR" and "LateMVR"). We report the results in Panel B of Table 5. For each model in Panel B of Table 5, we include the same control variables as in Panel A of Table 5. The results for late adopters are statistically highly significant and of slightly higher magnitude than the results for adopters as a whole. The results for early adopters decline in magnitude relative to the results in Panel $\mathrm{A}$, and in several specifications, are statistically insignificant. $F$-tests of the difference between EarlyMVR and LateMVR indicate that the difference is significant in Model $1(p$-value $=0.085)$, Model $4(p$ value $=0.001)$, and Model 5 ( $p$-value $=0.038)$.

To target more specifically the threshold level at which an MVR reduces the probability of a "withhold" vote, we ran regressions in which the dependent variable was, respectively, whether a director received a "withhold" vote in the 10 to 30 percent range, in the 30 to 40 percent range, or in the 40 to 50 percent range. Panel C of Table 5 reports the results. For each model in Panel C of Table 5, we include the same control variables as in Panel A of Table 5.

the same company received fewer "withhold" votes after the shift to an MVR, we expect that the standard deviation should increase after the shift. We found that, if anything, the standard deviation of the percentage of "withhold" votes and the incidence of Whvote30 declined for companies after the shift to an MVR. 


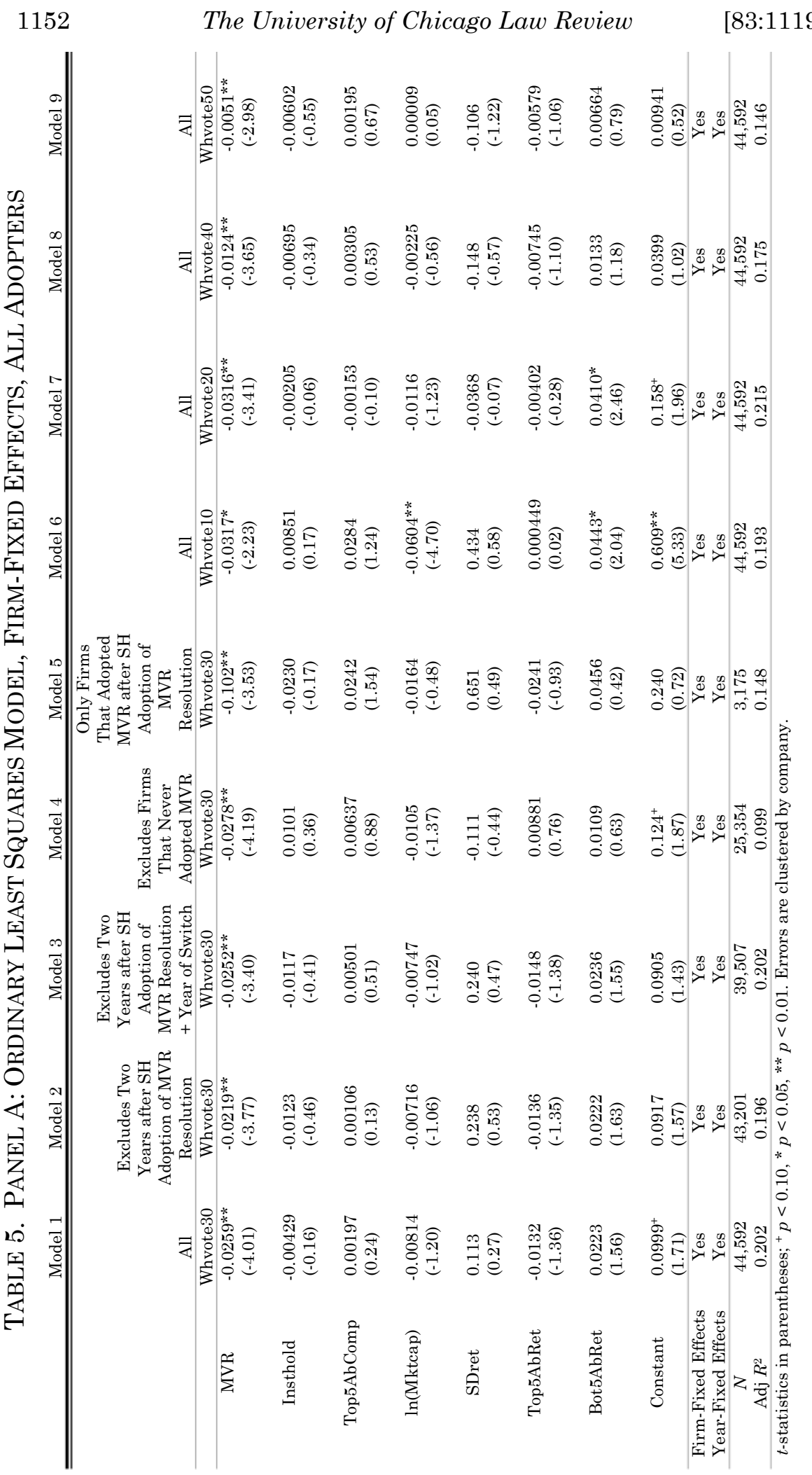


The results for late adopters indicate a statistically significant and economically meaningful reduction in the probabilities for the 30 to 40 percent and the 40 to 50 percent ranges after the adoption of an MVR. For early adopters, only the reduction in probability for the 40 to 50 percent range was significant after the adoption of an MVR. For both sets of adopters, there was no significant effect on the probability of receiving a "withhold" vote in the 10 to 30 percent range after the adoption of an MVR. $F$-tests of the difference between EarlyMVR and LateMVR indicate that the difference is significant only in Model 2 for the 30 to 40 percent range $(p$-value $=0.050)$. In the 30 to 40 percent range, majority voting thus corresponds to a reduction in the probability of a "withhold" vote for late adopters relative both to nonadopters and to early adopters, and to no statistically significant reduction for early adopters.

For further analysis, we matched firms that adopted majority voting with plurality voting firms in the same industry (measured by a two-digit Standard Industrial Classification (SIC) code). If there were more potential matches than MVR-adopting firms in the industry, we matched firms based on closeness in market capitalization. If there were more MVR-adopting firms than potential matches, we matched the MVR-adopting firms closest in market capitalization to potential matches and eliminated those MVRadopting firms without a match.

We then looked at the difference in the likelihood of a high "withhold" vote between directors at the firm that adopted majority voting and directors at the matched firm. We looked at this difference before the adoption of MVR and at the difference in this difference after the adoption of MVR ("Post-MVR Switch" is assigned the value of one for the time period after the switch to MVR and zero for the time period before the switch). "MVR Adopter" measures the difference between firms that would eventually adopt an MVR and their matches both before and after the adoption of majority voting; Post-MVR Switch measures the difference during the post-adoption period for both firms that adopted MVR and their respective matches. Using a difference-in-differences model allows us to control for unobservable corporate governance differences between our matched firms. Panel D of Table 5 reports logit models of a director receiving a "withhold" vote of more than a specified threshold using MVR Adopter, Post-MVR Switch, and "MVR Adopter $\times$ Post-MVR Switch" as independent variables. MVR Adopter $\times$ Post-MVR 
Switch measures the difference-in-difference variable. ${ }^{96}$ Model 1 in Panel D of Table 5 includes observations for all years for director elections in MVR Adopter firms and their matching nonswitching firms. Model 2 excludes observations for the two years following the adoption of a shareholder resolution calling for majority voting. Model 3 excludes, in addition, observations for the first year in which a company employed majority voting (regardless of whether there was a shareholder resolution). Model 4 includes observations from only MVR Adopter firms that adopted majority voting after shareholders adopted a proposal calling for the institution of majority voting and their matching nonswitching firms. We also ran the regressions (with the full set of observations for MVR Adopter firms and their matching firms) using "withhold"-vote thresholds of above 10 percent, 20 percent, and 40 percent, reported in Models 5 through 7 in Panel D of Table 5. ${ }^{97}$

The results of this analysis show a statistically significant negative coefficient for the interaction variable MVR Adopter $\times$ PostMVR Switch in each model in Panel D of Table 5-meaning that after the switch, firms that adopt majority voting are less likely to experience a high "withhold" vote relative to their matched firms than they were before they made the switch. In Model 1, for example, measured at the mean of all the independent variables, the difference-in-differences interaction variable corresponds to a 3.5 percentage point reduction in the probability of receiving a "withhold" vote above 30 percent. 98 These results, for adopters as a whole, are consistent with the respective results in the firm-fixed effects test.

96 We estimate Model 1 in Panel D of Table 5 using a logit model with errors clustered by company as follows:

$\operatorname{Prob}(\text { Whvote } 30=1)_{i}=F\left\{\alpha+\beta_{1 i}\right.$ MVR Adopter ${ }_{i}+\beta_{2 i}$ Post-MVR Switch $_{i}$

$+\beta_{3 i}$ MVR Adopter $\times$ Post-MVR Switch

$+\beta_{4 \mathrm{i}}$ Insthold $_{i}+\beta_{5 \mathrm{i}}$ Top 5 AbComp $_{\mathrm{i}}$

$+\beta_{6 i} \ln \left(\right.$ Mktcap $_{\mathrm{i}}+\beta_{7 \mathrm{i}}$ SDret $_{\mathrm{i}}+\beta_{8 \mathrm{i}}$ Top5AbRet $_{\mathrm{i}}$

$+\beta 9_{\mathrm{i}}$Bot$\left._{5} \mathrm{AbRet}_{\mathrm{i}}+\varepsilon_{\mathrm{i}}\right\}$

The other models in Panels D and E of Table 5 follow the same basic model with variations as noted in Table 5 and the text.

97 Unlike in Panel A of Table 5, we do not estimate a model using the threshold of above 50 percent for the "withhold" vote because none of the directors in MVR Adopter firms after the switch to MVR received a "withhold" vote of over 50 percent. In other words, MVR Adopter $\times$ Post-MVR Switch $=1$ is perfectly correlated with Whvote50 $=0$ in the model.

98 In the other models in Panel D of Table 5, the interaction terms correspond to the following reductions in the probability of receiving a "withhold" vote at the threshold specified in each model: 3.3 percentage points in Model 2, 3.4 percentage points in Model 3, 5.4 percentage points in Model 4, 6.2 percentage points in Model 5, 5.5 percentage points in Model 6, and 1.6 percentage points in Model 7. 


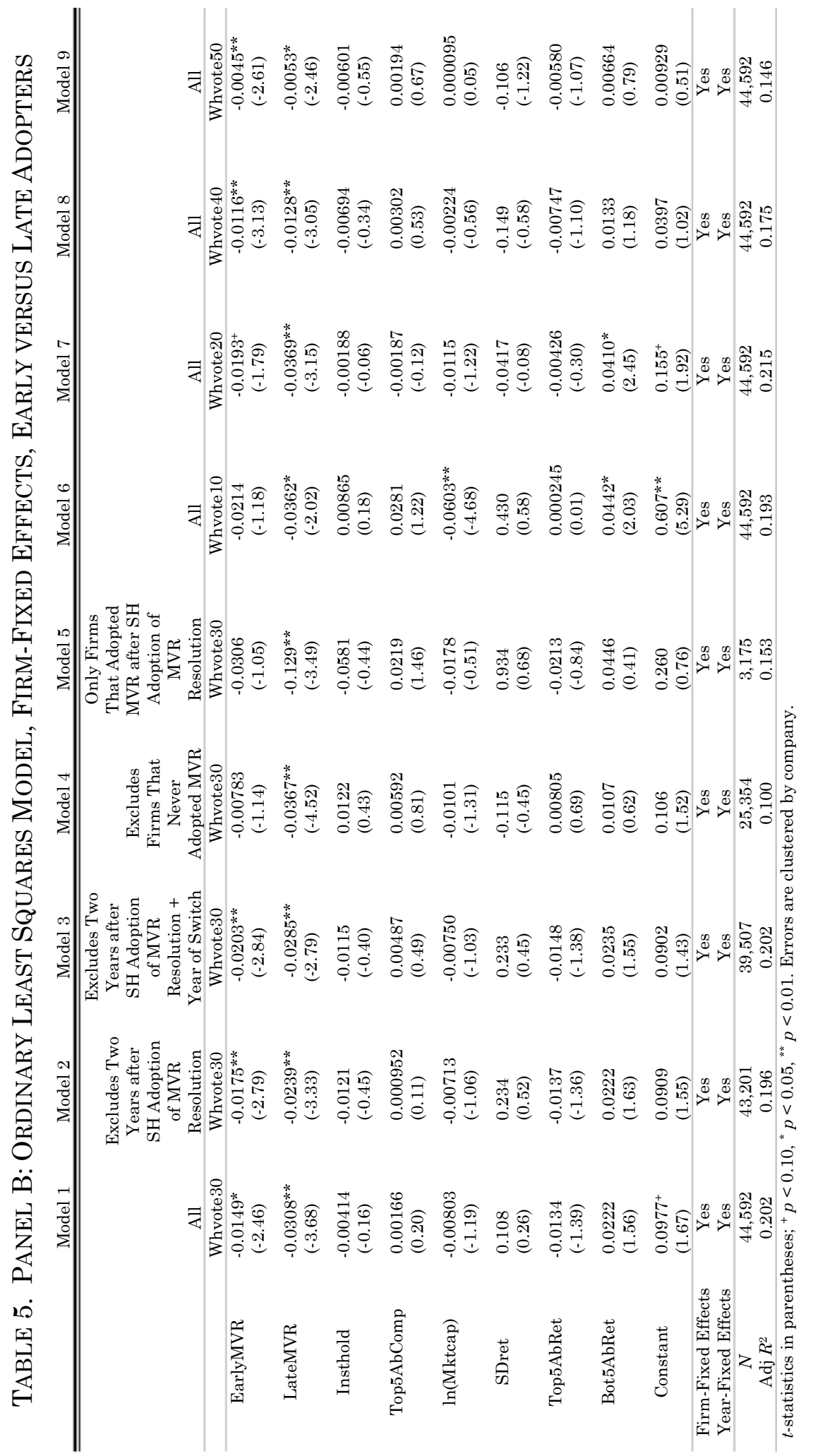


TABle 5. PANEL C: RANGeS

Model 1

Model 2

Model 3

\begin{tabular}{|c|c|c|c|}
\hline & $\begin{array}{c}\text { Whvote } \geq 10 \% \text { and } \\
\text { Whvote }<30 \%\end{array}$ & $\begin{array}{c}\text { Whvote } \geq 30 \% \text { and } \\
\text { Whvote }<40 \%\end{array}$ & $\begin{array}{c}\text { Whvote } \geq 40 \% \text { and } \\
\text { Whvote }<50 \%\end{array}$ \\
\hline EarlyMVR & $\begin{array}{l}-0.00650 \\
(-0.37)\end{array}$ & $\begin{array}{l}-0.00326 \\
(-0.68)\end{array}$ & $\begin{array}{l}-0.00712^{*} \\
(-2.26)\end{array}$ \\
\hline LateMVR & $\begin{array}{l}-0.00547 \\
(-0.36)\end{array}$ & $\begin{array}{l}-0.0180 * * \\
(-2.81)\end{array}$ & $\begin{array}{l}-0.00748^{*} \\
(-2.51)\end{array}$ \\
\hline Insthold & $\begin{array}{l}0.0128 \\
(0.30)\end{array}$ & $\begin{array}{l}0.00280 \\
(0.18)\end{array}$ & $\begin{array}{l}-0.000645 \\
(-0.04)\end{array}$ \\
\hline Top5AbComp & $\begin{array}{l}0.0264 \\
(1.26)\end{array}$ & $\begin{array}{l}-0.00136 \\
(-0.14)\end{array}$ & $\begin{array}{l}0.00109 \\
(0.28)\end{array}$ \\
\hline $\ln ($ Mktcap) & $\begin{array}{l}-0.0523^{* *} \\
(-4.55)\end{array}$ & $\begin{array}{l}-0.00579 \\
(-1.08)\end{array}$ & $\begin{array}{l}-0.00236 \\
(-0.69)\end{array}$ \\
\hline SDret & $\begin{array}{l}0.321 \\
(0.50)\end{array}$ & $\begin{array}{l}0.257 \\
(0.75)\end{array}$ & $\begin{array}{c}-0.0429 \\
(-0.19)\end{array}$ \\
\hline Top5AbRet & $\begin{array}{l}0.0137 \\
(0.82)\end{array}$ & $\begin{array}{l}-0.00595 \\
(-0.93)\end{array}$ & $\begin{array}{l}-0.00167 \\
(-0.51)\end{array}$ \\
\hline Bot5AbRet & $\begin{array}{l}0.0220 \\
(1.20)\end{array}$ & $\begin{array}{l}0.00897 \\
(1.12)\end{array}$ & $\begin{array}{l}0.00663 \\
(0.84)\end{array}$ \\
\hline Constant & $\begin{array}{l}0.509^{* *} \\
(4.94)\end{array}$ & $\begin{array}{l}0.0580 \\
(1.34)\end{array}$ & $\begin{array}{l}0.0305 \\
(0.92)\end{array}$ \\
\hline $\begin{array}{l}\text { Year Effects } \\
\text { Firm Effects }\end{array}$ & $\begin{array}{l}\text { Yes } \\
\text { Yes }\end{array}$ & $\begin{array}{l}\text { Yes } \\
\text { Yes }\end{array}$ & $\begin{array}{l}\text { Yes } \\
\text { Yes }\end{array}$ \\
\hline$N$ & 44,592 & 44,592 & 44,592 \\
\hline $\operatorname{Adj} R^{2}$ & 0.135 & 0.123 & 0.113 \\
\hline
\end{tabular}

We next split the MVR Adopter and Post-MVR Switch variables from Panel D of Table 5 into separate variables for early adopters ("MVR Adopter Early" and "Post-MVR Switch Early") and late adopters ("MVR Adopter Late" and "Post-MVR Switch Late"), and we included associated interaction terms. We report the results in Panel E of Table 5. When we segregate the sample by including separate dummy and interaction variables for early and late adopters, we find that the results for late adopters are robust. In Models 1 to 3 using the 30 percent threshold and in the regressions using the 10 percent, 20 percent, and 40 percent 
thresholds, the coefficient for the interaction variable is significant at the 1 percent level. The coefficient is insignificant only in Model 4, possibly due to the much smaller sample size. The coefficients for the interaction variables for late adopters are economically meaningful. Model 1, for example, measured at the mean of all the independent variables the difference-in-differences interaction variable for late adopters corresponds to a 2.8 percentage point reduction in the probability of receiving a "withhold" vote of above 30 percent. ${ }^{99}$

For early adopters, however, we find no significant results in Models 1 and 4 in Panel E of Table 5 and for thresholds of 10 percent (Model 5) and 20 percent (Model 6). We find weaker significant results in Models 2 and 3 (at the 10 percent and 5 percent level, respectively), and strong results in only the regression using a 40 percent threshold (Model 7). Note also that the coefficient for MVR Adopter Early is consistently and significantly negative (except in Model 4). This presents further evidence that early adopters had greater electoral success than other firms even before they adopted a majority vote rule - that is, evidence in favor of self-selection by early adopters. There is no equivalent evidence of self-selection by late adopters.

Overall, these results provide strong support for the proposition that the adoption of an MVR by late adopters reduced the likelihood of getting a "withhold" vote of 30 percent or above. We regard this result as most consistent with the deterrence or accountability hypothesis or some form of the electioneering hypothesis. While the shareholder-restraint hypothesis would also predict differential voting patterns, under that hypothesis the difference should be most pronounced around the 50 percent "withhold"-vote level at which the difference in voting rule transforms a message of dissatisfaction (under the plurality rule) into an actual effect on whether a nominee is elected (under the majority rule). For "withhold" votes of less than 50 percent, the message under both rules is similar. Thus, unless shareholders have

99 In the other models in Panel $\mathrm{E}$ of Table 5 in which the interaction term for late adopters is significant, the interaction terms for late adopters correspond to the following reductions in the probability of receiving a "withhold" vote at the threshold specified in each model: 2.5 percentage points in Model 2, 2.4 percentage points in Model 3, 6.5 percentage points in Model 5, 5.4 percentage points in Model 6, and 1.0 percentage point in Model 7. 
great difficulty in predicting which votes will be close, ${ }^{100}$ shareholder restraint should not affect the likelihood of receiving a "withhold" vote in excess of 30 percent. Similarly, since companies obtain intermediate vote results during the solicitation process, they would almost certainly know whether any director were at risk of receiving a majority "withhold" vote. ${ }^{101}$ Different voting rules, therefore, should not affect electioneering efforts aimed at shareholders (such as calling individual shareholders who tend to support company nominees) ${ }^{102}$ in a way that results in different probabilities of receiving a 30 percent "withhold" vote.

Deterrence or accountability, however, may be a more plausible account for a different likelihood of receiving a "withhold" vote of more than 30 percent. At the time that directors decide whether to take an action that could result in a high "withhold" vote, directors may not yet know whether the resulting "withhold" vote will be around 30 percent or closer to 50 percent. To avoid the risk of a majority "withhold" vote, directors may thus refrain from taking the offensive action. This decision would also reduce the risk of a 30 percent "withhold" vote. This is especially true for actions that are likely to cause a large increase in "withhold" votes. ${ }^{103}$ Similarly, companies may engage in differential efforts to lobby ISS not to issue a "withhold" recommendation (a form of electioneering) because an ISS recommendation is correlated with a substantial percentage of votes and an ISS "withhold" recommendation is a virtual prerequisite to a majority "withhold" vote. ${ }^{104}$

100 Although the outcomes of some shareholder votes are too close to call, a variety of mechanisms provide information to shareholders in advance of the actual vote, thereby allowing shareholders to take that information into account in making their voting decisions. See, for example, Jonathan Cheng and Min-Jeong Lee, As Vote Nears, Samsung Pulls Out All the Stops (Wall St J, July 15, 2015), online at http://www.wsj.com/articles/ as-vote-nears-samsung-pulls-out-all-the-stops-1436994473 (visited Feb 7, 2016) (Perma archive unavailable) (describing the alignment of various shareholders prior to the vote at a recent proxy contest at Samsung).

101 See Recommendations of the Investor Advisory Committee at *3 (cited in note 64) (describing Broadridge's practice of providing preliminary or intermediate voting results beginning ten to fifteen days prior to the annual meeting).

102 See Cheng and Lee, As Vote Nears, Samsung Pulls Out All the Stops (cited in note 100) (describing Samsung's efforts to solicit shareholder voting support, including delivering watermelons to individual shareholders).

103 For an analysis of which director actions are likely to correlate with a large "withhold" vote, see generally Yonca Ertimur, Fabrizio Ferri, and David Oesch, Understanding Uncontested Director Elections (unpublished manuscript), archived at http://perma.cc/QLR5-UXTB.

104 See Choi, Fisch, and Kahan, 3 Harv Bus L Rev at 63 (cited in note 28) (reporting that the probability of getting a "withhold" vote of at least 30 percent is only 0.1 percent 
Table 5. Panel D: Matched Sample

\begin{tabular}{|c|c|c|c|c|c|c|c|}
\hline & Model 1 & Model 2 & Model 3 & Model 4 & Model 5 & Model 6 & Model 7 \\
\hline & All & $\begin{array}{c}\text { Excl } 2 \text { Yrs } \\
\text { after SHs } \\
\text { Adopt MVR } \\
\text { Res }\end{array}$ & $\begin{array}{c}\text { Excl } 2 \text { Yrs } \\
\text { after SHs } \\
\text { Adopt MVR } \\
\text { Res + Yr of } \\
\text { Switch }\end{array}$ & $\begin{array}{l}\text { Only Firms } \\
\text { That Adopt } \\
\text { MVR after } \\
\text { SHs Adopt } \\
\text { MVR Res }\end{array}$ & All & All & All \\
\hline & Whvote 30 & Whvote 30 & Whvote30 & Whvote30 & Whvote10 & Whvote20 & Whvote 40 \\
\hline MVR Adopter & $\begin{array}{c}-0.327 \\
(-1.26)\end{array}$ & $\begin{array}{c}-0.307 \\
(-1.27)\end{array}$ & $\begin{array}{c}-0.293 \\
(-1.19)\end{array}$ & $\begin{array}{l}0.935 \\
(1.40)\end{array}$ & $\begin{array}{c}-0.208 \\
(-1.47)\end{array}$ & $\begin{array}{r}-0.335^{+} \\
(-1.70)\end{array}$ & $\begin{array}{c}-0.238 \\
(-0.74)\end{array}$ \\
\hline $\begin{array}{l}\text { Post-MVR } \\
\text { Switch }\end{array}$ & $\begin{array}{l}0.137 \\
(0.59)\end{array}$ & $\begin{array}{l}0.134 \\
(0.58)\end{array}$ & $\begin{array}{l}0.0887 \\
(0.32)\end{array}$ & $\begin{array}{c}-0.00558 \\
(-0.01)\end{array}$ & $\begin{array}{l}0.0774 \\
(0.61)\end{array}$ & $\begin{array}{l}0.0751 \\
(0.45)\end{array}$ & $\begin{array}{l}0.219 \\
(0.60)\end{array}$ \\
\hline $\begin{array}{l}\text { MVR Adopter } \\
\text { x Post-MVR } \\
\text { Switch }\end{array}$ & $\begin{array}{c}-1.862^{* *} \\
(-5.49)\end{array}$ & $\begin{array}{c}-1.841^{* *} \\
(-5.42)\end{array}$ & $\begin{array}{c}-2.001^{* *} \\
(-5.16)\end{array}$ & $\begin{array}{r}-2.290^{+} \\
(-1.96)\end{array}$ & $\begin{array}{c}-0.592^{* *} \\
(-3.42)\end{array}$ & $\begin{array}{c}-1.265^{* *} \\
(-5.04)\end{array}$ & $\begin{array}{c}-2.655^{* *} \\
(-5.30)\end{array}$ \\
\hline Insthold & $\begin{array}{l}0.603 \\
(1.25)\end{array}$ & $\begin{array}{l}0.728 \\
(1.51)\end{array}$ & $\begin{array}{l}0.628 \\
(1.24)\end{array}$ & $\begin{array}{l}1.510 \\
(1.24)\end{array}$ & $\begin{array}{l}0.372 \\
(1.31)\end{array}$ & $\begin{array}{l}0.436 \\
(1.14)\end{array}$ & $\begin{array}{l}1.374^{+} \\
(1.93)\end{array}$ \\
\hline Top5AbComp & $\begin{array}{l}0.631^{* *} \\
(2.60)\end{array}$ & $\begin{array}{l}0.00905 \\
(0.03)\end{array}$ & $\begin{array}{l}0.118 \\
(0.36)\end{array}$ & $\begin{array}{l}0.127 \\
(0.16)\end{array}$ & $\begin{array}{l}0.575^{* *} \\
(3.32)\end{array}$ & $\begin{array}{l}0.394^{+} \\
(1.78)\end{array}$ & $\begin{array}{l}0.976^{*} \\
(2.11)\end{array}$ \\
\hline $\ln ($ Mktcap) & $\begin{array}{c}-0.116 \\
(-1.18)\end{array}$ & $\begin{array}{c}-0.120 \\
(-1.31)\end{array}$ & $\begin{array}{c}-0.142 \\
(-1.40)\end{array}$ & $\begin{array}{c}-0.404 \\
(-1.25)\end{array}$ & $\begin{array}{c}-0.130 * \\
(-2.56)\end{array}$ & $\begin{array}{c}-0.0770 \\
(-0.94)\end{array}$ & $\begin{array}{c}-0.285^{*} \\
(-2.27)\end{array}$ \\
\hline SDret & $\begin{array}{c}23.91^{* *} \\
(3.27)\end{array}$ & $\begin{array}{c}26.49 * * \\
(3.29)\end{array}$ & $\begin{array}{c}27.83^{* *} \\
(3.31)\end{array}$ & $\begin{array}{c}29.33 \\
(1.55)\end{array}$ & $\begin{array}{l}12.28^{* *} \\
(2.94)\end{array}$ & $\begin{array}{l}18.21^{* *} \\
(3.18)\end{array}$ & $\begin{array}{r}21.23^{*} \\
(1.98)\end{array}$ \\
\hline Top5AbRet & $\begin{array}{c}-0.213 \\
(-0.65)\end{array}$ & $\begin{array}{c}-0.117 \\
(-0.35)\end{array}$ & $\begin{array}{c}-0.0915 \\
(-0.26)\end{array}$ & $\begin{array}{l}0.0972 \\
(0.12)\end{array}$ & $\begin{array}{l}0.0723 \\
(0.34)\end{array}$ & $\begin{array}{l}0.202 \\
(0.71)\end{array}$ & $\begin{array}{c}-0.144 \\
(-0.29)\end{array}$ \\
\hline Bot5AbRet & $\begin{array}{c}-0.104 \\
(-0.30)\end{array}$ & $\begin{array}{c}-0.0509 \\
(-0.14)\end{array}$ & $\begin{array}{c}-0.0325 \\
(-0.08)\end{array}$ & $\begin{array}{l}0.277 \\
(0.30)\end{array}$ & $\begin{array}{l}0.176 \\
(1.04)\end{array}$ & $\begin{array}{l}0.0728 \\
(0.28)\end{array}$ & $\begin{array}{c}-0.145 \\
(-0.25)\end{array}$ \\
\hline Constant & $\begin{array}{c}-3.214^{* * *} \\
(-3.98)\end{array}$ & $\begin{array}{c}-3.409^{* * *} \\
(-3.96)\end{array}$ & $\begin{array}{c}-3.203^{* *} \\
(-3.48)\end{array}$ & $\begin{array}{c}-1.787 \\
(-0.62)\end{array}$ & $\begin{array}{c}-1.249^{*} \\
(-2.45)\end{array}$ & $\begin{array}{l}-2.553^{* *} \\
(-3.50)\end{array}$ & $\begin{array}{c}-3.388^{* *} \\
(-3.06)\end{array}$ \\
\hline$N$ & 21,970 & 20,549 & 17,621 & 2,646 & 21,970 & 21,970 & 21,970 \\
\hline pseudo $R^{2}$ & 0.065 & 0.066 & 0.063 & 0.134 & 0.029 & 0.049 & 0.085 \\
\hline
\end{tabular}

Finally, an MVR may have more-subtle accountability effects. As some of us have argued elsewhere, the adoption of majority voting underlines the principle that shareholders are the bosses. ${ }^{105}$ This may lead to a change in board attitude and induce directors to adopt a more shareholder-centric view on other matters. ${ }^{106}$ Or, to the extent that a board was initially reluctant to

in the absence of a "withhold" recommendation from ISS, compared to a probability of 30 percent in the presence of an ISS "withhold" recommendation).

105 See Kahan and Rock, 94 BU L Rev at 2023-26 (cited in note 41).

106 See id at 2023-24. 
TABle 5. PANEL E: MATChed SAMPle-EARLY Versus Late ADOPTERS

\begin{tabular}{|c|c|c|c|c|c|c|c|}
\hline & Model 1 & Model 2 & Model 3 & Model 4 & Model 5 & Model 6 & Model 7 \\
\hline & All & $\begin{array}{c}\text { Excl } 2 \text { Yrs } \\
\text { after SHs } \\
\text { Adopt MVR } \\
\text { Res }\end{array}$ & $\begin{array}{c}\text { Excl } 2 \text { Yrs } \\
\text { after SHs } \\
\text { Adopt MVR } \\
\text { Res + Yr of } \\
\text { Switch }\end{array}$ & $\begin{array}{l}\text { Only Firms } \\
\text { that Adopt } \\
\text { MVR after } \\
\text { SHs Adopt } \\
\text { MVR Res }\end{array}$ & All & All & All \\
\hline & Whvote30 & Whvote30 & $\begin{array}{c}\text { Whvote3 } \\
0 \\
\end{array}$ & $\begin{array}{c}\text { Whvote3 } \\
0 \\
\end{array}$ & Whvote10 & Whvote20 & Whvote 40 \\
\hline $\begin{array}{l}\text { MVR } \\
\text { Adopter } \\
\text { Early }\end{array}$ & $\begin{array}{c}-1.337^{* *} \\
(-2.95)\end{array}$ & $\begin{array}{l}-1.191^{* *} \\
(-2.77)\end{array}$ & $\begin{array}{l}-1.151^{* *} \\
(-2.65)\end{array}$ & $\begin{array}{l}0.0803 \\
(0.07)\end{array}$ & $\begin{array}{l}-0.727^{* *} \\
(-2.89)\end{array}$ & $\begin{array}{l}-1.161^{* *} \\
(-2.77)\end{array}$ & $\begin{array}{r}-0.864^{+} \\
(-1.73)\end{array}$ \\
\hline $\begin{array}{l}\text { Post-MVR } \\
\text { Switch Early }\end{array}$ & $\begin{array}{l}0.213 \\
(0.66)\end{array}$ & $\begin{array}{l}0.239 \\
(0.87)\end{array}$ & $\begin{array}{l}0.113 \\
(0.36)\end{array}$ & $\begin{array}{l}0.699 \\
(0.64)\end{array}$ & $\begin{array}{l}0.123 \\
(0.66)\end{array}$ & $\begin{array}{l}0.121 \\
(0.50)\end{array}$ & $\begin{array}{l}0.314 \\
(0.63)\end{array}$ \\
\hline $\begin{array}{l}\text { MVR Adopter } \\
\text { Early } \times \text { Post- } \\
\text { MVR Switch } \\
\text { Early } \times \text { Post- } \\
\text { MVR Switch } \\
\text { Early }\end{array}$ & $\begin{array}{l}-0.735 \\
(-1.37)\end{array}$ & $\begin{array}{r}-0.972^{+} \\
(-1.90)\end{array}$ & $\begin{array}{c}-1.409 * \\
(-2.40)\end{array}$ & $\begin{array}{c}-1.463 \\
(-0.95)\end{array}$ & $\begin{array}{c}-0.0335 \\
(-0.11)\end{array}$ & $\begin{array}{c}-0.227 \\
(-0.49)\end{array}$ & $\begin{array}{l}-2.271^{* *} \\
(-3.16)\end{array}$ \\
\hline $\begin{array}{l}\text { MVR Adopter } \\
\text { Late }\end{array}$ & $\begin{array}{c}-0.260 \\
(-0.99)\end{array}$ & $\begin{array}{c}-0.246 \\
(-1.00)\end{array}$ & $\begin{array}{c}-0.239 \\
(-0.96)\end{array}$ & $\begin{array}{l}0.937 \\
(1.42)\end{array}$ & $\begin{array}{c}-0.158 \\
(-1.10)\end{array}$ & $\begin{array}{c}-0.270 \\
(-1.35)\end{array}$ & $\begin{array}{c}-0.191 \\
(-0.58)\end{array}$ \\
\hline $\begin{array}{l}\text { Post-MVR } \\
\text { Switch Late }\end{array}$ & $\begin{array}{l}0.0497 \\
(0.18)\end{array}$ & $\begin{array}{l}0.00036 \\
(0.00)\end{array}$ & $\begin{array}{l}0.0456 \\
(0.10)\end{array}$ & $\begin{array}{c}-2.955^{*} \\
(-2.42)\end{array}$ & $\begin{array}{l}0.0275 \\
(0.20)\end{array}$ & $\begin{array}{l}0.0281 \\
(0.13)\end{array}$ & $\begin{array}{l}0.107 \\
(0.29)\end{array}$ \\
\hline $\begin{array}{l}\text { MVR } \\
\text { Adopter Late } \\
\times \text { Post-MVR } \\
\text { Switch Latex } \\
\text { Post-MVR } \\
\text { Switch Late }\end{array}$ & $\begin{array}{l}-2.084^{* *} \\
(-5.11)\end{array}$ & * $\begin{array}{c}-1.855^{* *} \\
(-4.27)\end{array}$ & $\begin{array}{c}-1.650 * * \\
(-2.79)\end{array}$ & $\begin{array}{c}-0.897 \\
(-0.56)\end{array}$ & $\begin{array}{l}-0.683^{* *} \\
(-3.41)\end{array}$ & $\begin{array}{l}-1.646^{* *} \\
(-5.22)\end{array}$ & $\begin{array}{l}-2.436 * * \\
(-4.02)\end{array}$ \\
\hline Insthold & $\begin{array}{l}0.612 \\
(1.27)\end{array}$ & $\begin{array}{l}0.733 \\
(1.52)\end{array}$ & $\begin{array}{l}0.642 \\
(1.26)\end{array}$ & $\begin{array}{l}2.214^{+} \\
(1.75)\end{array}$ & $\begin{array}{l}0.382 \\
(1.35)\end{array}$ & $\begin{array}{l}0.447 \\
(1.18)\end{array}$ & $\begin{array}{l}1.382^{+} \\
(1.94)\end{array}$ \\
\hline $\begin{array}{l}\text { Top5AbCom } \\
\mathrm{p}\end{array}$ & $\begin{array}{l}0.605^{*} \\
(2.46)\end{array}$ & $\begin{array}{c}-0.0144 \\
(-0.05)\end{array}$ & $\begin{array}{l}0.103 \\
(0.31)\end{array}$ & $\begin{array}{l}0.0198 \\
(0.03)\end{array}$ & $\begin{array}{l}0.559 * * \\
(3.22)\end{array}$ & $\begin{array}{l}0.370^{+} \\
(1.67)\end{array}$ & $\begin{array}{l}0.960 * \\
(2.06)\end{array}$ \\
\hline $\ln ($ Mktcap) & $\begin{array}{l}-0.115 \\
(-1.14)\end{array}$ & $\begin{array}{c}-0.121 \\
(-1.31)\end{array}$ & $\begin{array}{c}-0.137 \\
(-1.34)\end{array}$ & $\begin{array}{c}-0.372 \\
(-1.28)\end{array}$ & $\begin{array}{c}-0.129 * \\
(-2.49)\end{array}$ & $\begin{array}{c}-0.0767 \\
(-0.91)\end{array}$ & $\begin{array}{c}-0.286^{*} \\
(-2.20)\end{array}$ \\
\hline SDret & $\begin{array}{c}22.41^{* *} \\
(3.04)\end{array}$ & $\begin{array}{c}24.88^{* *} \\
(3.06)\end{array}$ & $\begin{array}{l}26.74^{* *} \\
(3.15)\end{array}$ & $\begin{array}{r}37.06^{+} \\
(1.88)\end{array}$ & $\begin{array}{l}11.28^{* *} \\
(2.69)\end{array}$ & $\begin{array}{l}16.82^{* *} \\
(2.92)\end{array}$ & $\begin{array}{r}20.02^{+} \\
(1.77)\end{array}$ \\
\hline Top5AbRet & $\begin{array}{c}-0.226 \\
(-0.69)\end{array}$ & $\begin{array}{c}-0.131 \\
(-0.39)\end{array}$ & $\begin{array}{c}-0.103 \\
(-0.29)\end{array}$ & $\begin{array}{c}-0.0479 \\
(-0.06)\end{array}$ & $\begin{array}{l}0.0653 \\
(0.31)\end{array}$ & $\begin{array}{l}0.194 \\
(0.68)\end{array}$ & $\begin{array}{c}-0.162 \\
(-0.32)\end{array}$ \\
\hline Bot5AbRet & $\begin{array}{c}-0.0994 \\
(-0.28)\end{array}$ & $\begin{array}{c}-0.0449 \\
(-0.12)\end{array}$ & $\begin{array}{l}-0.00566 \\
(-0.01)\end{array}$ & $\begin{array}{l}0.340 \\
(0.37)\end{array}$ & $\begin{array}{l}0.176 \\
(1.02)\end{array}$ & $\begin{array}{l}0.0671 \\
(0.26)\end{array}$ & $\begin{array}{c}-0.136 \\
(-0.23)\end{array}$ \\
\hline Constant & $\begin{array}{l}-3.184^{* *} \\
(-3.89)\end{array}$ & $* \begin{array}{c}-3.354^{* *} \\
(-3.91)\end{array}$ & $\begin{array}{l}-3.217 * * \\
(-3.51)\end{array}$ & $\begin{array}{c}-2.883 \\
(-1.19) \\
\end{array}$ & $\begin{array}{r}-1.233^{*} \\
(-2.40) \\
\end{array}$ & $\begin{array}{l}-2.525^{* *} \\
(-3.43)\end{array}$ & $\begin{array}{c}-3.352^{* *} \\
(-2.95)\end{array}$ \\
\hline$N$ & 21,970 & 20,549 & 17,621 & 2,646 & 21,970 & 21,970 & 21,970 \\
\hline pseudo $R^{2}$ & 0.067 & 0.068 & 0.064 & 0.174 & 0.031 & 0.052 & 0.086 \\
\hline
\end{tabular}


adopt majority voting, the fact that proponents of majority voting eventually prevailed may be a show of strength that induces directors to offer less resistance to shareholder-rights advocates on other matters. ${ }^{107}$

By contrast, our results for early adopters provide support for the causation hypothesis only for levels of "withhold" votes in excess of 40 percent. Such an effect would be compatible with any of the three forms of causation hypotheses that we discussed: deterrence or accountability, electioneering, and shareholder restraint.

3. The deterrence or accountability hypothesis: the effect of the MVR on primary conduct.

To examine the deterrence hypothesis more directly, one could examine whether board actions, rather than electoral success, change after the adoption of majority voting. This question goes to the core of the claim that majority voting increases board accountability. An increase in shareholder support for directors after the switch to majority voting does not necessarily mean that the directors are behaving differently; voting results can alternatively be the result of electioneering by the issuer or restraint by shareholders under an MVR. The distinction between the deterrence hypothesis and the electioneering and shareholder-restraint hypotheses lies in whether majority voting affects primary board behavior (making the board less likely to take actions that generate shareholder opposition) or whether it affects the voting outcome given primary board behavior (reducing "withhold" votes due to electioneering or shareholder restraint). Evidence that primary board behavior changes after the adoption of majority voting would be evidence supporting the deterrence hypothesis, as distinguished from the electioneering and shareholder-restraint hypotheses. Evidence that the voting outcomes change after the adoption of majority voting even if there is no change in primary board behavior, in turn, would constitute evidence in favor of the electioneering or shareholder-restraint hypotheses, to the exclusion of the deterrence hypothesis.

In prior research, three of us have identified two types of board behavior that are associated with a substantial increase in "withhold" votes: a director's failure to attend at least 75 percent of the board or committee meetings ("Attendless75") and a board's failure to implement a shareholder proposal that had been adopted by

107 Id at 2024-26. 
shareholders ("Failure to Implement"). ${ }^{108}$ Attendless75, in particular, is strongly associated both with the likelihood of ISS issuing a "withhold" recommendation and with the expected "withhold" vote given an ISS "withhold" recommendation. ${ }^{109}$ If an MVR has any deterrent effect, it is especially likely to be reflected in Attendless75, given the substantial effect of such failure on "withhold" votes and the dichotomous nature of the variable. ${ }^{110}$

Both of these measures, however, also have problems. Companies can to some extent manipulate whether a director failed to attend at least 75 percent of the board or committee meetings. For example, if a director is just below that threshold, a company could schedule an additional committee meeting, if only a brief one, to enable the director to cross it. Similarly, many companies adopt, or promise to adopt, shareholder proposals before they come up for a vote, thereby inducing withdrawal of the proposal or rendering the proposal moot (and hence excludable from the proxy statement). The implementation rate of proposals that came to a vote and received majority support is thus a potentially biased measure of a company's responsiveness to shareholder proposals. Moreover, to the extent that firms that employ an MVR and firms that employ a PVR differ in the degree of shareholderoriented governance, as indicated by the earlier results, they may differ not just in their inclination to implement proposals but also in the likelihood that they will receive proposals that will be supported by a majority of shareholders. On the one hand, if their governance is more shareholder oriented, shareholders may perceive fewer problems that they want to address through proposals. On the other hand, if these firms are perceived to be more shareholder friendly, shareholders may make more proposals because they perceive a higher likelihood of adoption. Controlling for such endogeneity is thus a necessity.

In addition, Attendless75 may not be typical of other actions that induce a "withhold" vote. A failure to attend board meetings is one of the relatively few actions in which individual directors

108 See Choi, Fisch, and Kahan, 82 S Cal L Rev at 661-62, 671-73 (cited in note 18). 109 See id.

110 The 75 percent threshold is defined by SEC disclosure rules and ISS "withhold" recommendation policies. See 17 CFR $\S 229.407(b)(1)$ (requiring companies to "[n]ame each incumbent director who during the last full fiscal year attended fewer than 75 percent of the aggregate of: [ ] [t]he total number of meetings of the board of directors ... [and] [t]he total number of meetings held by all committees of the board on which he served"); Gregory, How to Address ISS \& Glass Lewis Policy Changes (cited in note 60) (describing ISS's policy of using 75 percent attendance as a threshold for "withhold" recommendations). 
act contrary to the interest of the board as a whole. In a sense, they reflect director-board agency costs (in addition to directorshareholder agency costs). By contrast, most other actions that induce "withhold" votes-such as not implementing a shareholder proposal, approving abnormally high CEO compensation, or having business relations with the company-are approved by the board and are, at least arguably, in the best interest of the company (and thus reflect actual or perceived board-shareholder agency costs).

In Table 6, we provide summary statistics with respect to director attendance. The first column of Table 6 provides the percentage of directors who failed to attend the requisite percentage of meetings (Attendless75). The second column of Table 6 provides the percentage of directors who failed to attend the requisite percentage of meetings and also received an ISS "withhold" recommendation ("Attendless75 × ISS WH Rec"). The first column can be interpreted as a failure to attend for invalid as well as valid reasons (for example, temporary illness). The second column can be interpreted as a more precise measure of a failure to attend for invalid reasons, but it may also include the effect of ISS biases and of electioneering (that is, companies lobbying ISS not to issue a "withhold" recommendation).

To control for selection effects and possible time trends, we ran regressions using, respectively, Attendless75 and Attendless $75 \times$ ISS WH Rec as dependent variables, with independent variables including MVR, firm- and year-fixed effects, and the same additional controls as in Table 5.111 Our results, reported in Models 1 and 2 of Table 7, indicate that an MVR is associated with a statistically significant reduction in Attendless 75 and Attendless $75 \times$ ISS WH Rec for adopters as a whole. These results present direct evidence that adoption of an MVR results in a reduced likelihood that directors will fail to attend at least 75 percent of the board meetings. We next test the effect of MVRs on early and late adopters, respectively (Models 3 and 4 of Table 7).

111 We estimate Model 1 in Table 7 using ordinary least squares with errors clustered by company as follows:

Attendless75 $=\alpha+\beta_{1 i}$ MVR $_{i}+\beta_{2 i}$ Insthold $_{i}$

$+\beta_{3 \mathrm{i}}$ Top 5 AbComp $_{\mathrm{i}}+\beta_{4 \mathrm{i}} \ln (\text { Mktcap })_{\mathrm{i}}$

$+\beta_{5 i}$ SDret $_{i}+\beta_{6 i}$ Top5AbRet $_{i}$

$+\beta_{7_{\mathrm{i}} \text { Bot} \text { AbRet }_{\mathrm{i}}}+$ Firm Effects + Year Effect $+\varepsilon_{\mathrm{i}}$

The other models in Table 7 follow the same basic model with variations as noted in Table 7 and the text. 
The coefficients on LateMVR are negative and significant at the 10 percent level for both Attendless75 and Attendless75 $\times$ ISS WH Rec. For early adopters, the coefficient on EarlyMVR is negative and significant only for Attendless75 (Model 3 of Table 7). In both Models 3 and $4, F$-tests of the differences between LateMVR and EarlyMVR are not significantly different from zero. We thus do not find evidence that the impact of adopting MVR on Attendless 75 and Attendless75 $\times$ ISS WH Rec differs between early and late adopters of MVR.

We ran similar regressions using the failure to implement a shareholder proposal that received majority support as the dependent variable (Failure to Implement). ${ }^{112}$ Since the decision to implement a proposal is company-wide, these regressions were run on a company level. Results are reported in columns 5 and 6 of Table 7. The coefficients for whether the company has adopted majority voting are insignificant. ${ }^{113}$ We thus find no evidence of increased accountability with respect to this measure of shareholder friendliness. ${ }^{114}$

112 For this study, we collected data on shareholder governance proposals that received more "for" votes than "against" votes during the 2007 to 2012 proxy seasons and in which the implementation of the proposal would have resulted in an SEC filing. We omitted proposals to implement majority voting, since these proposals affect only firms with plurality voting. We further omitted "say on pay" proposals for 2009 and subsequent years because federal "say on pay" legislation was already pending when these proposals would have been implemented. See Dodd-Frank Wall Street Reform and Consumer Protection Act $\S 951$, Pub L No 111-203, 124 Stat 1376, 1899 (2010), codified at 15 USC $\S 78 n-1$ (requiring the SEC to adopt rules implementing an advisory shareholder vote on executive compensation). When a firm had multiple shareholder proposals that received more "for" votes than "against" votes in a particular proxy season, we treated the firm as not implementing a proposal if it failed to implement at least one of the proposals. Overall, the implementation rate was significantly higher for MVR than for PVR companies (82.8 percent versus 56.7 percent). The requirement that implementation trigger an SEC filing increases the likelihood that either implementation or a failure to implement would be readily visible to both ISS and shareholders.

113 In unreported robustness checks including only companies in which a proposal had received majority support, the MVR variable was similarly insignificant in regressions that included firm-fixed effects.

114 We note that we cannot control for the quality of the shareholder proposals that an issuer receives, a factor that may influence our results if majority voting issuers receive higher- or lower-quality shareholder proposals than plurality voting issuers. 


\section{TABLE 6. SumMARY StATISTICS: FRACTION OF DiRECTORS Who FAILED TO ATTEND 75 PERCENT OF MEETINGS}

\begin{tabular}{lll} 
& Attendless75 & $\begin{array}{l}\text { Attendless } 75 \times \\
\text { ISS WH Rec }\end{array}$ \\
\hline \hline PVR & $0.606 \%$ & $0.405 \%$ \\
MVR & $0.344 \%$ & $0.113 \%$ \\
Difference & $0.262 \% * *$ & $0.292 \%^{* *}$ \\
Standard Error of & $0.08 \%$ & $0.06 \%$ \\
Difference & & \\
EarlyMVR & $0.403 \%$ & $0.124 \%$ \\
LateMVR & $0.212 \%$ & $0.088 \%$ \\
$\begin{array}{l}\text { Difference } \\
\text { EarlyMVR and LateMVR }\end{array}$ & $0.191 \% *$ & $0.036 \%$ \\
$\begin{array}{l}\text { Standard Error of } \\
\text { Difference }\end{array}$ & $0.09 \%$ & $0.05 \%$ \\
EarlyMVR and LateMVR & $0.191 \%$ & $0.036 \%$ \\
$\begin{array}{l}\text { Difference } \\
\text { PVR and EarlyMVR }\end{array}$ & $0.203 \% *$ & $0.281 \% * *$ \\
Standard Error of & $0.09 \%$ & $0.08 \%$ \\
Difference & & \\
$\begin{array}{l}\text { Difference } \\
\text { PVR and LateMVR }\end{array}$ & $0.394 \% * *$ & $0.316 \% * *$ \\
Standard Error of & & \\
Difference & $0.13 \%$ & \\
\hline
\end{tabular}

The Difference row reports the difference between the PVR and MVR rows. The Standard Error rows reports the standard error of the differences, clustered at the company level. For an example of a comparison of director characteristics using the standard error clustered at the company level, see Vyacheslav Fos and Margarita Tsoutsoura, Shareholder Democracy in Play: Career Consequences of Proxy Contests, $114 \mathrm{~J}$ Fin Econ 316, 322 (2014). The Difference rows also report the statistical significance of the differences computed using the standard error as follows: ${ }^{+} p<0.10$, ${ }^{*} p<0.05,{ }^{* *} p<0.01$. 
TABle 7. PRIMARY BoARD BehaVIOR: REgREssion REsults

\begin{tabular}{|c|c|c|c|c|c|c|}
\hline & Model 1 & Model 2 & Model 3 & Model 4 & Model 5 & Model 6 \\
\hline & $\begin{array}{c}\text { Attendless } \\
75\end{array}$ & $\begin{array}{c}\text { Attendless } \\
75 \times \text { ISS } \\
\text { WH Rec }\end{array}$ & $\begin{array}{c}\text { Attendless } \\
75\end{array}$ & $\begin{array}{c}\text { Attendless } \\
75 \times \text { ISS } \\
\text { WH Rec }\end{array}$ & $\begin{array}{l}\text { Failure to } \\
\text { Implement }\end{array}$ & $\begin{array}{l}\text { Failure to } \\
\text { Implement }\end{array}$ \\
\hline MVR & $\begin{array}{l}-0.00397^{*} \\
(-2.36)\end{array}$ & $\begin{array}{l}-0.00292^{*} \\
(-2.30)\end{array}$ & & & $\begin{array}{l}-0.000222 \\
(-0.03)\end{array}$ & \\
\hline EarlyMVR & & & $\begin{array}{l}-0.00609^{+} \\
(-1.88)\end{array}$ & $\begin{array}{l}-0.00292 \\
(-1.51)\end{array}$ & & $\begin{array}{l}-0.00286 \\
(-0.18)\end{array}$ \\
\hline LateMVR & & & $\begin{array}{l}-0.00304^{+} \\
(-1.71)\end{array}$ & $\begin{array}{l}-0.00292^{+} \\
(-1.95)\end{array}$ & & $\begin{array}{l}0.000869 \\
(0.10)\end{array}$ \\
\hline Insthold & $\begin{array}{l}0.0000067 \\
(0.00)\end{array}$ & $\begin{array}{l}0.00182 \\
(0.25)\end{array}$ & $\begin{array}{l}-0.0000220 \\
(-0.00)\end{array}$ & $\begin{array}{l}0.00182 \\
(0.25)\end{array}$ & $\begin{array}{c}-0.00906 \\
(-0.41)\end{array}$ & $\begin{array}{c}-0.00910 \\
(-0.41)\end{array}$ \\
\hline $\begin{array}{l}\text { Top5AbCo } \\
\text { mp }\end{array}$ & $\begin{array}{l}0.00307 \\
(1.57)\end{array}$ & $\begin{array}{l}0.000376 \\
(0.38)\end{array}$ & $\begin{array}{l}0.00313 \\
(1.61)\end{array}$ & $\begin{array}{l}0.000376 \\
(0.38)\end{array}$ & $\begin{array}{l}-0.00126 \\
(-0.10)\end{array}$ & $\begin{array}{l}-0.00121 \\
(-0.10)\end{array}$ \\
\hline $\ln ($ Mktcap) & $\begin{array}{l}-0.00179 \\
(-1.08)\end{array}$ & $\begin{array}{l}-0.00109 \\
(-0.81)\end{array}$ & $\begin{array}{l}-0.00181 \\
(-1.09)\end{array}$ & $\begin{array}{l}-0.00109 \\
(-0.81)\end{array}$ & $\begin{array}{l}0.00399 \\
(0.57)\end{array}$ & $\begin{array}{l}0.00397 \\
(0.57)\end{array}$ \\
\hline SDret & $\begin{array}{l}0.0685 \\
(0.74)\end{array}$ & $\begin{array}{l}0.0611 \\
(0.79)\end{array}$ & $\begin{array}{l}0.0692 \\
(0.75)\end{array}$ & $\begin{array}{l}0.0611 \\
(0.79)\end{array}$ & $\begin{array}{c}-0.0380 \\
(-0.12)\end{array}$ & $\begin{array}{c}-0.0370 \\
(-0.12)\end{array}$ \\
\hline Top5AbRet & $\begin{array}{l}-0.000633 \\
(-0.30)\end{array}$ & $\begin{array}{l}-0.00121 \\
(-0.74)\end{array}$ & $\begin{array}{l}-0.000591 \\
(-0.28)\end{array}$ & $\begin{array}{l}-0.00121 \\
(-0.74)\end{array}$ & $\begin{array}{c}-0.0138 \\
(-1.46)\end{array}$ & $\begin{array}{c}-0.0138 \\
(-1.46)\end{array}$ \\
\hline Bot5AbRet & $\begin{array}{l}-0.00692 * * \\
(-2.60)\end{array}$ & $\begin{array}{l}-0.00438^{*} \\
(-1.97)\end{array}$ & $\begin{array}{l}-0.00691^{* *} \\
(-2.60)\end{array}$ & $\begin{array}{l}-0.00438^{*} \\
(-1.98)\end{array}$ & $\begin{array}{l}0.00965 \\
(0.78)\end{array}$ & $\begin{array}{l}0.00962 \\
(0.77)\end{array}$ \\
\hline Constant & $\begin{array}{l}0.0205 \\
(1.24)\end{array}$ & $\begin{array}{l}0.0111 \\
(0.82)\end{array}$ & $\begin{array}{l}0.0209 \\
(1.27)\end{array}$ & $\begin{array}{l}0.0111 \\
(0.81)\end{array}$ & $\begin{array}{l}-0.00679 \\
(-0.12)\end{array}$ & $\begin{array}{c}-0.00651 \\
(-0.11)\end{array}$ \\
\hline $\begin{array}{l}\text { Year-Fixed } \\
\text { Effects } \\
\text { Firm-Fixed }\end{array}$ & Yes & Yes & Yes & Yes & Yes & Yes \\
\hline Effects & Yes & Yes & Yes & Yes & Yes & Yes \\
\hline $\begin{array}{l}N \\
\text { Adj } R^{2}\end{array}$ & $\begin{array}{c}44,888 \\
0.011 \\
\end{array}$ & $\begin{array}{c}44,888 \\
0.015 \\
\end{array}$ & $\begin{array}{c}44,888 \\
0.011 \\
\end{array}$ & $\begin{array}{c}44,888 \\
0.015 \\
\end{array}$ & $\begin{array}{l}6,932 \\
0.067 \\
\end{array}$ & $\begin{array}{l}6,932 \\
0.067 \\
\end{array}$ \\
\hline
\end{tabular}

4. The electioneering and shareholder-restraint hypotheses: majority withhold votes given primary conduct.

Both the deterrence and the selection hypotheses posit that nominees of majority voting companies behave differently than nominees of plurality voting companies (albeit for different reasons) and that this difference in behavior explains the differential vote patterns. But it is also possible that the same primary director behavior generates a different electoral outcome depending on the voting regime. Evidence of such a change in the voting outcome would constitute evidence in favor of electioneering and shareholder restraint. 
To test for this possibility, we compiled a sample of director nominees who committed equivalent "offenses" against shareholderfriendly governance. We then calculated whether the probability of that nominee receiving a majority "withhold" vote ${ }^{115}$ differs depending on whether the nominee is elected under a PVR or an MVR. A higher likelihood for nominees subject to plurality voting would be consistent with electioneering by majority voting companies or restrained voting by shareholders of majority voting companies.

We identify the following five offenses:

- The nominee receiving an ISS "withhold" recommendation (ISS WH Rec);

- The nominee missing more than 25 percent of board and committee meetings (Attendless75);

- The nominee receiving an ISS "withhold" recommendation and missing more than 25 percent of board and committee meetings (Attendless $75 \times$ ISS WH Rec);

- The nominee being an incumbent director of a company that has failed to implement a shareholder proposal that has received majority support (Failure to Implement);

- The nominee receiving an ISS "withhold" recommendation and being an incumbent director of a company that has failed to implement a shareholder proposal that has received majority support ("Failure to Implement $\times$ ISS WH Rec").

Note that some of these categories of offensive conduct include having received an ISS "withhold" recommendation. In these categories, a differential likelihood of receiving a majority "withhold" vote could reflect electioneering oriented toward shareholders. Any electioneering that takes the form of lobbying ISS not to issue a "withhold" recommendation may not be reflected in a differential likelihood of receiving a majority "withhold" vote.

Panel A of Table 8 reports the summary statistics. In each category, the probability of receiving a majority "withhold" vote was substantially lower for nominees subject to an MVR than for nominees subject to a PVR. As Panel A shows, the likelihood of receiving a majority "withhold" vote given the primary behavior

115 We focus here on majority "withhold" votes rather than high "withhold" votes on the assumption that both issuers and shareholders may perceive the legal significance of a majority "withhold" vote differently under an MVR, despite the evidence of the limited frequency with which directors who fail to receive majority support lose their board positions. 
is significantly higher for plurality voting companies than for majority voting companies under each of the five measures. The differences, nonetheless, are significant only for ISS WH Rec, Attendless75, and Failure to Implement.

The results in Panel A, however, may be driven by selection effects. Different firms may have varying prior information on whether offensive conduct is likely to result in a majority "withhold" vote. For example, firms in which the board controls a high fraction of the votes are presumably less likely to receive a majority "withhold" vote than firms in which the board controls only a low fraction of votes. Firms that adopt an MVR may be those that are more sensitive to these priors than firms that choose to retain a PVR. Such MVR-adopting firms may generally be better able (whether under an MVR or a PVR) to assess when engaging in offensive conduct will not result in a majority "withhold" vote, and thus may engage in offensive conduct only in circumstances when it is unlikely to result in a majority "withhold" vote.

To address these selection effects, we ran firm-fixed-effects regressions. The dependent variable in these regressions is the likelihood of receiving a majority "withhold" vote. Because our a priori view is that electioneering or shareholder restraint will be most likely to take place when a vote otherwise may cross the 50 percent "withhold"-vote threshold, we focus on the likelihood of receiving a majority "withhold" vote to test the impact of electioneering or shareholder restraint. As independent variables, we include - in addition to firm-fixed effects—a dummy variable for an MVR, a dummy variable for one of the five "offenses," an interaction of these dummy variables, and the same controls as in the models in Table 5. ${ }^{116}$ If, given the same offensive conduct, an MVR is associated with a reduced likelihood of a majority "withhold" vote, we expect a negative coefficient for the interaction dummy. We further predict a negative coefficient for the MVR dummy and a positive coefficient for the "offense"-conduct variable. These results are reported in Panel B of Table $8 .{ }^{117}$

116 Note that the variables in the models in Panels B and C of Table 8 that include ISS WH Rec test only for electioneering of votes directly, not indirectly via ISS lobbying.

117 We estimate Model 1 in Panel B of Table 8 using ordinary least squares with errors clustered by company as follows:

Whvote $50_{i}=\alpha+\beta_{1 i} M_{V R}+\beta_{2 i}$ ISS WH Reci

$+\beta_{3 i}$ MVR $\times$ ISS WH Rec $i+\beta_{4 i}$ Insthold $_{i}$

$+\beta_{5 i}$ Top5AbComp $p_{i}+\beta_{6 i} \ln (\text { Mktcap })_{i}$

$+\beta_{7 \mathrm{i}}$ SDret $_{i}+\beta_{8 \mathrm{i}}$ Top5AbRet $_{\mathrm{i}}$

$+\beta_{9 i}$ Bot5AbRet $_{i}+$ Firm Effects + Year Effect $+\varepsilon_{i}$ 
TABle 8. Panel A: Majority "WithholD”-Vote Outcomes

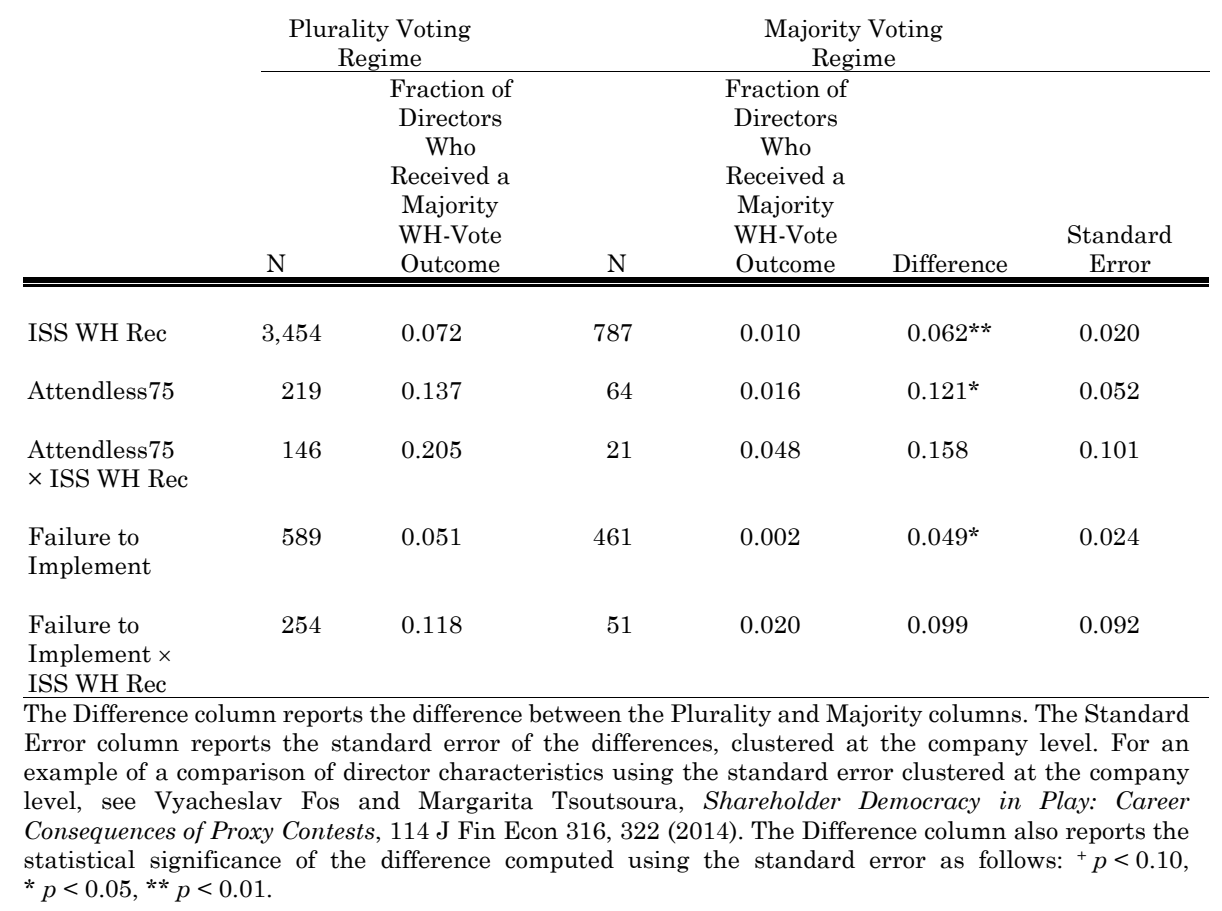

The other models in Panels $\mathrm{B}$ and $\mathrm{C}$ of Table 8 follow the same basic model with variations as noted in Table 8 and the text. 
TABle 8. PANEL B: REgREssions: MAJORITY "WithHOLD"-Vote OUTCOMES, FIRM-FIXED EFFECTS REGRESSIONS

\begin{tabular}{|c|c|c|c|c|c|}
\hline & $\begin{array}{c}\text { Model } 1 \\
\text { Whvote50 }\end{array}$ & $\begin{array}{c}\text { Model } 2 \\
\text { Whvote50 }\end{array}$ & $\begin{array}{c}\text { Model } 3 \\
\text { Whvote50 }\end{array}$ & $\begin{array}{c}\text { Model } 4 \\
\text { Whvote50 }\end{array}$ & $\begin{array}{c}\text { Model } 5 \\
\text { Whvote50 }\end{array}$ \\
\hline MVR & $\begin{array}{l}-0.00197 \\
(-1.35)\end{array}$ & $\begin{array}{l}-0.00418^{*} \\
(-2.53)\end{array}$ & $\begin{array}{l}-0.00425^{*} \\
(-2.58)\end{array}$ & $\begin{array}{l}-0.00395^{*} \\
(-2.22)\end{array}$ & $\begin{array}{l}-0.00402^{*} \\
(-2.34)\end{array}$ \\
\hline ISS WH Rec & $\begin{array}{l}0.0697 * * \\
(7.92)\end{array}$ & & & & \\
\hline MVR $\times$ ISS WH Rec & $\begin{array}{l}-0.0652^{* *} \\
(-7.36)\end{array}$ & & & & \\
\hline Attendless 75 & & $\begin{array}{l}0.140 * * \\
(4.84)\end{array}$ & & & \\
\hline MVR $\times$ Attendless 75 & & $\begin{array}{l}-0.122^{* *} \\
(-3.59)\end{array}$ & & & \\
\hline $\begin{array}{l}\text { Attendless } 75 \times \text { ISS WH } \\
\text { Rec }\end{array}$ & & & $\begin{array}{l}0.204^{* *} \\
(5.05)\end{array}$ & & \\
\hline $\begin{array}{l}\text { MVR } \times \\
\text { Attendless } 75 \times \text { ISS WH } \\
\text { Rec }\end{array}$ & & & $\begin{array}{c}-0.146^{*} \\
(-2.12)\end{array}$ & & \\
\hline Failure to Implement & & & & $\begin{array}{l}0.0339 * \\
(2.24)\end{array}$ & \\
\hline $\begin{array}{l}\text { MVR } \times \text { Failure to } \\
\text { Implement }\end{array}$ & & & & $\begin{array}{c}-0.0280^{+} \\
(-1.82)\end{array}$ & \\
\hline $\begin{array}{l}\text { Failure to Implement } \times \\
\text { ISS WH Rec }\end{array}$ & & & & & $\begin{array}{l}0.0960 * * \\
(2.87)\end{array}$ \\
\hline $\begin{array}{l}\text { MVR } \times \text { Failure to } \\
\text { Implement } \\
\times \text { ISS WH Rec }\end{array}$ & & & & & $\begin{array}{c}-0.0658 \\
(-1.49)\end{array}$ \\
\hline Insthold & $\begin{array}{l}-0.00393 \\
(-0.39)\end{array}$ & $\begin{array}{l}-0.00595 \\
(-0.55)\end{array}$ & $\begin{array}{l}-0.00621 \\
(-0.58)\end{array}$ & $\begin{array}{l}-0.00613 \\
(-0.56)\end{array}$ & $\begin{array}{l}-0.00613 \\
(-0.56)\end{array}$ \\
\hline Top5AbComp & $\begin{array}{l}0.00345 \\
(1.02)\end{array}$ & $\begin{array}{l}0.00159 \\
(0.55)\end{array}$ & $\begin{array}{l}0.00195 \\
(0.67)\end{array}$ & $\begin{array}{l}0.00178 \\
(0.57)\end{array}$ & $\begin{array}{l}0.00226 \\
(0.66)\end{array}$ \\
\hline $\ln ($ Mktcap) & $\begin{array}{l}0.000404 \\
(0.21)\end{array}$ & $\begin{array}{l}0.000198 \\
(0.11)\end{array}$ & $\begin{array}{l}0.000165 \\
(0.09)\end{array}$ & $\begin{array}{l}0.0000159 \\
(0.01)\end{array}$ & $\begin{array}{l}-0.000114 \\
(-0.06)\end{array}$ \\
\hline SDret & $\begin{array}{l}-0.137 \\
(-1.55)\end{array}$ & $\begin{array}{l}-0.116 \\
(-1.35)\end{array}$ & $\begin{array}{c}-0.117 \\
(-1.37)\end{array}$ & $\begin{array}{l}-0.116 \\
(-1.31)\end{array}$ & $\begin{array}{l}-0.105 \\
(-1.21)\end{array}$ \\
\hline Top5AbRet & $\begin{array}{l}-0.00509 \\
(-1.01)\end{array}$ & $\begin{array}{l}-0.00550 \\
(-1.01)\end{array}$ & $\begin{array}{l}-0.00550 \\
(-1.01)\end{array}$ & $\begin{array}{l}-0.00559 \\
(-1.03)\end{array}$ & $\begin{array}{l}-0.00575 \\
(-1.06)\end{array}$ \\
\hline Bot5AbRet & $\begin{array}{l}0.00493 \\
(0.62)\end{array}$ & $\begin{array}{l}0.00733 \\
(0.87)\end{array}$ & $\begin{array}{l}0.00725 \\
(0.87)\end{array}$ & $\begin{array}{l}0.00635 \\
(0.75)\end{array}$ & $\begin{array}{l}0.00643 \\
(0.76)\end{array}$ \\
\hline Constant & $\begin{array}{l}0.000625 \\
(0.03)\end{array}$ & $\begin{array}{l}0.00763 \\
(0.42) \\
\end{array}$ & $\begin{array}{l}0.00818 \\
(0.46) \\
\end{array}$ & $\begin{array}{l}0.00956 \\
(0.52) \\
\end{array}$ & $\begin{array}{l}0.0101 \\
(0.55) \\
\end{array}$ \\
\hline $\begin{array}{l}\text { Year-Fixed Effects } \\
\text { Firm-Fixed Effects }\end{array}$ & $\begin{array}{l}\text { Yes } \\
\text { Yes } \\
\end{array}$ & $\begin{array}{l}\text { Yes } \\
\text { Yes } \\
\end{array}$ & $\begin{array}{l}\text { Yes } \\
\text { Yes }\end{array}$ & $\begin{array}{l}\text { Yes } \\
\text { Yes }\end{array}$ & $\begin{array}{l}\text { Yes } \\
\text { Yes }\end{array}$ \\
\hline $\begin{array}{l}N \\
\text { Adj } R^{2}\end{array}$ & $\begin{array}{c}44,592 \\
0.190 \\
\end{array}$ & $\begin{array}{l}44,592 \\
0.165\end{array}$ & $\begin{array}{c}44,592 \\
0.174 \\
\end{array}$ & $\begin{array}{c}44,592 \\
0.148\end{array}$ & $\begin{array}{c}44,592 \\
0.153 \\
\end{array}$ \\
\hline
\end{tabular}


TABLE 8. PANEL C: REgRESSIONS: MAJORITY “WithHOLD”-Vote OUTCOMES, FIRM-FIXED EFFECTS, EARLY AND LATE ADOPTERS

\begin{tabular}{|c|c|c|c|c|c|}
\hline & $\begin{array}{c}\text { Model } 1 \\
\text { Whvote50 } \\
\end{array}$ & $\begin{array}{c}\text { Model } 2 \\
\text { Whvote50 } \\
\end{array}$ & $\begin{array}{c}\text { Model } 3 \\
\text { Whvote50 } \\
\end{array}$ & $\begin{array}{c}\text { Model } 4 \\
\text { Whvote50 } \\
\end{array}$ & $\begin{array}{c}\text { Model } 5 \\
\text { Whvote50 } \\
\end{array}$ \\
\hline EarlyMVR & $\begin{array}{l}-0.00153 \\
(-0.88)\end{array}$ & $\begin{array}{l}-0.00317^{+} \\
(-1.86)\end{array}$ & $\begin{array}{l}-0.00358^{*} \\
(-2.15)\end{array}$ & $\begin{array}{l}-0.00337^{+} \\
(-1.85)\end{array}$ & $\begin{array}{l}-0.00342^{+} \\
(-1.82)\end{array}$ \\
\hline LateMVR & $\begin{array}{l}-0.00243 \\
(-1.30)\end{array}$ & $\begin{array}{l}-0.00474^{*} \\
(-2.24)\end{array}$ & $\begin{array}{l}-0.00468^{*} \\
(-2.22)\end{array}$ & $\begin{array}{l}-0.00445^{*} \\
(-2.00)\end{array}$ & $\begin{array}{l}- \\
0.00446^{*} \\
(-2.09)\end{array}$ \\
\hline ISS WH Rec & $\begin{array}{l}0.0698^{* *} \\
(7.92)\end{array}$ & & & & \\
\hline $\begin{array}{l}\text { EarlyMVR } \times \text { ISS WH } \\
\text { Rec }\end{array}$ & $\begin{array}{l}-0.0690^{* *} \\
(-7.96)\end{array}$ & & & & \\
\hline LateMVR $\times$ ISS WH Rec & $\begin{array}{l}-0.0496^{* * *} \\
(-3.38)\end{array}$ & & & & \\
\hline Attendless 75 & & $\begin{array}{l}0.140^{* * *} \\
(4.84)\end{array}$ & & & \\
\hline $\begin{array}{l}\text { EarlyMVR } \times \\
\text { Attendless } 75\end{array}$ & & $\begin{array}{l}-0.140^{* *} \\
(-4.85)\end{array}$ & & & \\
\hline $\begin{array}{l}\text { LateMVR } \times \\
\text { Attendless } 75\end{array}$ & & $\begin{array}{c}-0.0450 \\
(-0.48)\end{array}$ & & & \\
\hline $\begin{array}{l}\text { Attendless } 75 \times \text { ISS WH } \\
\text { Rec }\end{array}$ & & & $\begin{array}{l}0.204^{* *} \\
(5.05)\end{array}$ & & \\
\hline $\begin{array}{l}\text { EarlyMVR } \times \\
\text { Attendless } 75 \times \text { ISS WH } \\
\text { Rec }\end{array}$ & & & $\begin{array}{l}-0.203^{* *} \\
(-5.02)\end{array}$ & & \\
\hline $\begin{array}{l}\text { LateMVR } \times \\
\text { Attendless } 75 \times \text { ISS WH } \\
\text { Rec }\end{array}$ & & & $\begin{array}{l}0.0539 \\
(0.24)\end{array}$ & & \\
\hline Failure to Implement & & & & $\begin{array}{l}0.0344^{*} \\
(2.27)\end{array}$ & \\
\hline $\begin{array}{l}\text { EarlyMVR } \times \text { Failure to } \\
\text { Implement }\end{array}$ & & & & $\begin{array}{l}-0.0337^{*} \\
(-2.24)\end{array}$ & \\
\hline $\begin{array}{l}\text { LateMVR } \times \text { Failure to } \\
\text { Implement }\end{array}$ & & & & $\begin{array}{l}-0.00937 \\
(-0.49)\end{array}$ & \\
\hline $\begin{array}{l}\text { Failure to Implement } \times \\
\text { ISS WH Rec }\end{array}$ & & & & & $\begin{array}{l}0.0959 * * \\
(2.87)\end{array}$ \\
\hline $\begin{array}{l}\text { EarlyMVR } \times \text { Failure to } \\
\text { Implement } \times \text { ISS WH } \\
\text { Rec }\end{array}$ & & & & & $\begin{array}{l}- \\
0.0931^{* *} \\
(-2.81)\end{array}$ \\
\hline $\begin{array}{l}\text { LateMVR } \times \text { Failure to } \\
\text { Implement } \times \text { ISS WH } \\
\text { Rec }\end{array}$ & & & & & $\begin{array}{l}0.0937 \\
(0.49)\end{array}$ \\
\hline Insthold & $\begin{array}{l}-0.00393 \\
(-0.39)\end{array}$ & $\begin{array}{l}-0.00594 \\
(-0.55)\end{array}$ & $\begin{array}{l}-0.00629 \\
(-0.58)\end{array}$ & $\begin{array}{l}-0.00608 \\
(-0.55)\end{array}$ & $\begin{array}{l}-0.00621 \\
(-0.57)\end{array}$ \\
\hline Top5AbComp & $\begin{array}{l}0.00332 \\
(0.99)\end{array}$ & $\begin{array}{l}0.00158 \\
(0.54)\end{array}$ & $\begin{array}{l}0.00197 \\
(0.68)\end{array}$ & $\begin{array}{l}0.00172 \\
(0.55)\end{array}$ & $\begin{array}{l}0.00201 \\
(0.59)\end{array}$ \\
\hline $\ln ($ Mktcap) & $\begin{array}{l}0.000427 \\
(0.23)\end{array}$ & $\begin{array}{l}0.000240 \\
(0.13)\end{array}$ & $\begin{array}{l}0.000238 \\
(0.13)\end{array}$ & $\begin{array}{l}-0.0000376 \\
(-0.02)\end{array}$ & $\begin{array}{l}- \\
0.000241 \\
(-0.13)\end{array}$ \\
\hline SDret & $\begin{array}{l}-0.137 \\
(-1.55)\end{array}$ & $\begin{array}{c}-0.115 \\
(-1.34)\end{array}$ & $\begin{array}{c}-0.114 \\
(-1.34)\end{array}$ & $\begin{array}{c}-0.114 \\
(-1.29)\end{array}$ & $\begin{array}{c}-0.103 \\
(-1.19)\end{array}$ \\
\hline
\end{tabular}


TABLe 8. PANel C, CONTINUED

\begin{tabular}{llllcc}
\hline & Model 1 & Model 2 & Model 3 & Model 4 & Model 5 \\
& Whvote50 & Whvote50 & Whvote50 & Whvote50 & Whvote50 \\
\hline Top5AbRet & -0.00506 & -0.00549 & -0.00554 & -0.00564 & -0.00551 \\
& $(-1.01)$ & $(-1.01)$ & $(-1.02)$ & $(-1.04)$ & $(-1.01)$ \\
Bot5AbRet & 0.00495 & 0.00736 & 0.00735 & 0.00628 & 0.00635 \\
& $(0.62)$ & $(0.88)$ & $(0.88)$ & $(0.75)$ & $(0.75)$ \\
Constant & 0.000401 & 0.00714 & 0.00752 & 0.00986 & 0.0112 \\
& $(0.02)$ & $(0.40)$ & $(0.42)$ & $(0.54)$ & $(0.60)$ \\
\hline Year-Fixed Effects & Yes & Yes & Yes & Yes & Yes \\
Firm-Fixed Effects & Yes & Yes & Yes & Yes & Yes \\
\hline$N$ & 44,592 & 44,592 & 44,592 & 44,592 & 44,592 \\
Adj $R^{2}$ & 0.190 & 0.165 & 0.175 & 0.148 & 0.153 \\
\hline$t$-statistics in parentheses $;{ }^{+} p<0.10,{ }^{*} p<0.05,{ }^{* *} p<0.01$. & Errors are clustered by company.
\end{tabular}

Consistent with our predictions, the coefficient for MVR is significantly negative in four of the five regressions and the coefficient for the primary-conduct variable is significantly positive in each of the five regressions in Panel B of Table 8. In four regressions, the coefficient for the interaction variable between one of the offenses and MVR is significantly negative. Thus, even after controlling for endogeneity through firm-fixed effects, given similar conduct, MVR companies have a lower likelihood of receiving a majority "withhold" vote than do PVR companies.

For each model in Panel B, we split the MVR variable into one for early adopters (EarlyMVR) and one for late adopters (LateMVR). We report the results in Panel $\mathrm{C}$ of Table 8. The interaction terms for the early adopters are statistically significant in all five regressions. Moreover, the sum of the "offense" variable and the interaction term between the "offense" variable and EarlyMVR is close to zero for each model, indicating that the negative effects of the offense on director voting are largely eliminated for the early adopters. Evidence for the electioneering or shareholderrestraint hypotheses therefore exists for the early adopters. For late adopters, however, only the interaction coefficient for the ISS "withhold" recommendation is significant.

The results in Table 8 could in principle reflect gradations in offensive conduct that are not captured by our variables. Thus, for example, the conduct of directors of plurality voting firms who receive ISS "withhold" recommendations may be systematically worse than the conduct of directors of majority voting firms who receive ISS "withhold" recommendations. While this may be plausible for some of our conduct measures, we think it is unlikely with respect to conduct defined as "failure to attend at least 75 
percent of meetings and ISS 'withhold' recommendation" (Attendless75 × ISS WH Rec) and "failure to implement and ISS "withhold' recommendation" (Failure to Implement $\times$ ISS WH Rec).

Moreover, the coefficient estimates for the interaction variable for early adopters are virtually identical to (and of the opposite sign as) the estimates for the respective-conduct variable. Thus, for example, in Model 3 of Panel C, the coefficient estimate for "failure to attend at least 75 percent of meetings and ISS 'withhold' recommendation" (Attendless75 × ISS WH Rec) is 0.204, indicating a 20.4 percentage point increase in the likelihood that a director at a plurality voting firm that engaged in such conduct would receive a majority "withhold" vote. The coefficient estimate for "failure to attend at least 75 percent of meetings and ISS "withhold' recommendation" (Attendless $75 \times$ ISS WH Rec) interacted with early adopter (EarlyMVR) is -0.203 , indicating a 20.3 percentage point decrease in the likelihood for a director at an earlyadopting majority voting firm relative to a plurality voting firm. We are dubious that discrepancies of this magnitude can be explained by gradations in offensiveness within the group of directors who failed to attend at least 75 percent of meetings and also received an ISS "withhold" recommendation.

In sum, the results in Table 8 present strong evidence of electioneering or shareholder restraint for early adopters, although we are unable, on the basis of this test, to distinguish between the two hypotheses. By contrast, there is only weak evidence that electioneering or shareholder restraint affect the voting pattern for late adopters.

\section{CONCLUSION}

Director nominees at companies that adopt majority voting are far less likely to receive high levels of votes against them than are directors at plurality voting companies. The challenge is to explain why. Is it because firms likely to receive high levels of "withhold" votes are less likely to adopt majority voting, or does the adoption of majority voting cause a firm to become less likely to receive high levels of "withhold" votes? And if the latter, is the causal effect due to directors taking fewer actions likely to offend shareholder sensibilities, due to companies campaigning harder to reduce the level of "withhold" votes, or due to shareholders becoming more reluctant to withhold their vote because they anticipate that voting against a director nominee is not a mere protest vote but may have real consequences? 
In our analysis, we obtain different results for early and late adopters of majority voting, in both the reasons for and the effects of adoption. For early adopters, we find evidence of selection effects: these companies had more electoral success and more shareholder-oriented governance before they adopted majority voting than firms that did not adopt majority voting. We conclude that early adopters largely adopted majority voting voluntarily. By contrast, we do not find statistically significant evidence that late adopters differ from nonadopters.

For both early and late adopters, we find statistically significant evidence that the adoption of majority voting affected voting results subsequent to the switch to majority voting. The reasons for this effect may differ, however, for these two sets of firms. For late adopters, we conclude that adoption of majority voting led to more shareholder-friendly governance, either because of the heightened threat that a majority "withhold" vote would lead to ouster from the board or because the adoption of majority voting made boards more sensitive to shareholder concerns. We find little evidence that late adopters enhanced their electoral fortunes through electioneering or that they benefited from shareholders' restraint.

For early adopters, by contrast, we find evidence consistent with either electioneering or shareholder restraint. Outside of the specific context of inducing directors to attend sufficient board and committee meetings to meet the 75 percent attendance threshold, however, it is unclear whether adoption of majority voting had much effect on director behavior for early adopters.

The difference in our results for early and late adopters has broader lessons for understanding the spread of corporate governance innovations. In principle, there are two plausible strategies that shareholders can use to select targets for governance reform. The first is to target companies that are most in need of governance reform, at which the reform will have the most impact and the company is arguably least able to resist. The second strategy is to target companies that already have the most shareholderfriendly governance, at which, although the reform will have the least impact, the company is most amenable to adopting the innovation (either because it is committed to shareholder-friendly governance or because it realizes that the innovation will make little difference). Once the innovation has become established at shareholder-friendly companies, shareholders might then proceed to target those companies that are most in need of the reform, at a 
time when these companies are less able to resist because the reform is less novel or has even become a governance norm. At least for the introduction of majority voting, one of the most widely adopted innovations over the last decade, the results suggest that shareholders may have pursued the second strategy and been highly successful.

The implications of this study may apply to the spread of other governance reforms. Current innovations, for example, include proxy access and empowering a percentage of shareholders to call a special meeting. ${ }^{118}$ As with majority voting, institutional investors have urged issuers to adopt these changes. It will be interesting to examine which of the strategies investors pursue to induce companies to adopt these changes and whether that strategy succeeds.

That governance innovations can spread in different ways has important implications for the conduct and interpretation of empirical studies of corporate governance. First, this study highlights the importance of segregating early and late adopters of the innovations, because the reasons for and the effects of adoption may differ systematically between these groups. Second, one needs to be cautious in extrapolating results from studies conducted relatively early in the adoption process. Depending on the strategy employed by shareholders seeking governance reform, the effect of an innovation may be significantly higher or lower for early adopters than for subsequent adopters.

118 See, for example, Patrick McGurn and Edward Kamonjoh, The Latest in Governance Reform - Proxy Access (ISS), archived at http://perma.cc/3ZM5-RZWE (explaining that "[f]rom a near-standing start this season, proxy access has bolted to the lead of the 2015 shareholder proposal race"); Ning Chiu and Richard Sandler, Spotlight on Shareholder Proposals: Special Meetings (Davis Polk \& Wardwell LLP, July 19, 2011), archived at http://perma.cc/S634-XBLG (explaining that, as of 2011, "[a]s a result of targeted [shareholder] activism in the last few years, more than half of the S\&P 500 companies now allow shareholders to call special meetings"). 
APPENDIX. VARIABLE DEFINITIONS

COMPANY-DIRECTOR-LEVEL VARIABLES

\begin{tabular}{|c|c|}
\hline Variable Name & Definition \\
\hline Whvote & $\begin{array}{l}\text { The ratio of "withhold" votes over the } \\
\text { sum of "withhold" votes plus "for" votes } \\
\text { for the director. }\end{array}$ \\
\hline Whvote $X$ & $\begin{array}{l}\text { Equal to one if Whvote is greater than } \\
\text { or equal to } X \text { percent; zero otherwise. }\end{array}$ \\
\hline Attendless 75 & $\begin{array}{l}\text { Equal to one if the director attended } \\
\text { less than } 75 \text { percent of the company's } \\
\text { director meetings according to IRRC, } \\
\text { measured at the time of the annual } \\
\text { meeting; zero otherwise. }\end{array}$ \\
\hline ISS WH Rec & $\begin{array}{l}\text { Equal to one if ISS gave the director } \\
\text { a "withhold" recommendation; zero } \\
\text { otherwise. }\end{array}$ \\
\hline \multicolumn{2}{|c|}{ COMPANY-YEAR-LEVEL VARIABLES } \\
\hline Variable Name & Definition \\
\hline MVR & $\begin{array}{l}\text { Equal to one if the company uses an } \\
\text { MVR to elect directors at the time of } \\
\text { the annual meeting; zero otherwise. }\end{array}$ \\
\hline EarlyMVR & $\begin{array}{l}\text { Equal to one if the company uses an } \\
\text { MVR to elect directors at the time of } \\
\text { the annual meeting and had adopted } \\
\text { MVR by } 2009 \text {; zero otherwise. }\end{array}$ \\
\hline LateMVR & $\begin{array}{l}\text { Equal to one if the company uses an } \\
\text { MVR to elect directors at the time of } \\
\text { the annual meeting and adopted MVR } \\
\text { after } 2009 \text {; zero otherwise. }\end{array}$ \\
\hline $\begin{array}{l}\text { Avg ISS WH Rec } \\
\text { Prior } 2 \text { Years }\end{array}$ & $\begin{array}{l}\text { The mean for the prior two years of the } \\
\text { percentage of ISS "withhold" recom- } \\
\text { mendations for director nominees of } \\
\text { the company. }\end{array}$ \\
\hline $\begin{array}{c}\text { Any ISS WH Rec } \\
\text { Prior } 2 \text { Years }\end{array}$ & $\begin{array}{l}\text { Equal to one if any of the director nom- } \\
\text { inees at a company received an ISS } \\
\text { "withhold" recommendation in the } \\
\text { prior two years; zero otherwise. }\end{array}$ \\
\hline
\end{tabular}


Avg WH Vote Prior 2 The average percentage of "withhold" Years votes for all director nominees at the company for the prior two years.

High WH Vote Prior The highest "withhold" vote for any di2 Years rector nominee at the company for the prior two years.

Any Director ReEqual to one if any director nominee at ceived $>X \% \mathrm{WH}$ the company received more than $X$ perVote Prior 2 Years cent "withhold" votes in an election dur-

Delaware ing the prior two years; zero otherwise.

PPill

ClassBd

CumVote

Top5AbRet

Bot5AbRet Equal to one if the company is incorporated in Delaware at the time of the annual meeting; zero otherwise. Equal to one if the company has a poison pill at the time of the annual meeting; zero otherwise. Equal to one if the company has a classified board at the time of the annual meeting; zero otherwise. Equal to one if the company uses a cumulative voting regime to elect directors at the time of the annual meeting; zero otherwise.

Equal to one if the abnormal return for the one-year period prior to the annual meeting for the company is in the top 5 percent of the sample; zero otherwise. The "abnormal return" is defined as the difference between the raw oneyear holding period return for the company and the one-year holding period return for the CRSP value-weighted market index.

Equal to one if the abnormal return for the one-year period prior to the annual meeting for the company is in the bottom 5 percent of the sample; zero otherwise. The "abnormal return" is defined as the difference between the raw one-year holding period return for the 
company and the one-year holding period return for the CRSP valueweighted market index.

SDret Standard deviation of raw returns for the company for one year prior to the annual meeting.

Mktcap Market capitalization of the company in millions of dollars measured on the last trade date prior to the annual meeting.

Insthold The percentage of outstanding shares of the company held by institutional investors as of the end of the March quarter in the meeting year.

CharterAmend Equal to one if the company is incorporated in a state that requires a charter amendment to adopt majority voting to elect directors; zero otherwise.

Failure to Equal to one if the company failed to Implement implement a shareholder proposal that received majority support during the relevant time period; zero otherwise. For this study, we collected data on shareholder governance proposals that received more "for" votes than "against" votes during the 2007 to 2012 proxy seasons and in which the implementation of the proposal would have resulted in an SEC filing. We omitted proposals to implement majority voting, because these proposals affect only firms with plurality voting. We further omitted "say on pay" proposals for 2009 and subsequent years because federal "say on pay" legislation was already pending when these proposals would have been implemented. When a firm had multiple shareholder proposals that received more "for" votes than "against" votes in a particular proxy 
season, we treated the firm as not implementing a proposal if it failed to implement at least one of the proposals.

Top5AbComp Equal to one if the total excess compensation for the CEO of the company was in the top 5 percent of the sample; zero otherwise. We define "total excess CEO compensation" as the difference between the total CEO compensation for the year prior to the annual meeting (as provided by the Compustat executive compensation database) minus the expected total CEO compensation. We calculate the expected total CEO compensation by first estimating an ordinary least squares model as follows (following a model suggested to us by Professor Martijn Cremers):

$$
\ln (\text { Total CEO Compensation })=\alpha+
$$
$\beta_{1} \ln ($ Mktcap $)+\beta_{2}$ One_Year Abnormal_Holding_Period_Return $+\beta_{3}$ One_Year_Standard_Dev

+ Year Effects + Industry Effects $+\varepsilon$

We then use the predicted total CEO compensation based on this model as the expected total CEO compensation. Industry effects were based on twodigit Standard Industrial Classification (SIC) codes.

One_Year_Abnormal_Holding_Period_Return is defined as the difference between the holding period return and the value-weighted CRSP market index for the same period.

Post-MVR Switch Equal to one for either an MVR Adopter or match company in the time period after the MVR Adopter has switched to MVR; zero otherwise. We matched firms that adopted majority 
voting (MVR Adopter) with plurality voting companies in the same industry (measured by a two-digit Standard Industrial Classification (SIC) code). If there were more potential matches than MVR-adopting companies in the industry, we matched based on closeness in market capitalization. If there were more MVR-adopting companies than potential matches, we matched the MVR-adopting firms closest in market capitalization to potential matches and eliminated those MVRadopting companies without a match.

Post-MVR Switch Equal to one for either an MVR Adopter Early Early or match company in the time period after the MVR Adopter Early has switched to MVR; zero otherwise.

Post-MVR Switch Equal to one for either an MVR Adopter Late Late or match company in the time period after the MVR Adopter Late has switched to MVR; zero otherwise.

COMPANY-LEVEL VARIABLES

Variable Name Definition

\begin{tabular}{cl}
\hline \hline MVR Adopter & $\begin{array}{l}\text { Equal to one if the company eventually } \\
\text { adopted MVR during the time period of } \\
\text { our study; zero otherwise. } \\
\text { Equal to one in all years if the com- } \\
\text { pany adopted MVR at any point up to } \\
\text { 2009; zero otherwise. } \\
\text { Equal to one in all years if the com- } \\
\text { pany adopted MVR at any point after } \\
\text { 2009 and during the time period of our } \\
\text { study; zero otherwise. }\end{array}$
\end{tabular}

